\title{
Plasticity in medaka gonadotropes via cell proliferation and phenotypic conversion
}

\author{
Romain Fontaine, Eirill Ager-Wick, Kjetil Hodne and Finn-Arne Weltzien \\ Department of Preclinical Sciences and Pathology, Faculty of Veterinary Medicine, Norwegian University of Life Sciences, Oslo, Norway
}

Correspondence should be addressed to F-A Weltzien: finn-arne.weltzien@nmbu.no

\begin{abstract}
Follicle-stimulating hormone (Fsh) and luteinizing hormone (Lh) produced by the gonadotropes play a major role in control of reproduction. Contrary to mammals and birds, Lh and Fsh are mostly produced by two separate cell types in teleost. Here, we investigated gonadotrope plasticity, using transgenic lines of medaka (Oryzias latipes) where DsRed2 and hrGfpll are under the control of the fshb and lhb promotors respectively. We found that Fsh cells appear in the pituitary at $8 \mathrm{dpf}$, while Lh cells were previously shown to appear at $14 \mathrm{dpf}$. Similar to Lh cells, Fsh cells show hyperplasia from juvenile to adult stages. Hyperplasia is stimulated by estradiol. Both Fsh and Lh cells show hypertrophy during puberty with similar morphology. They also share similar behavior, using their cellular extensions to make networks. We observed bi-hormonal gonadotropes in juveniles and adults but not in larvae where only mono-hormonal cells are observed, suggesting the existence of phenotypic conversion between Fsh and Lh in later stages. This is demonstrated in cell culture, where some Fsh cells start to produce Lh $\beta$, a phenomenon enhanced by gonadotropin-releasing hormone (Gnrh) stimulation. We have previously shown that medaka Fsh cells lack Gnrh receptors, but here we show that with time in culture, some Fsh cells start responding to Gnrh, while fshb mRNA levels are significantly reduced, both suggestive of phenotypic change. All together, these results reveal high plasticity of gonadotropes due to both estradiol-sensitive proliferation and Gnrh promoted phenotypic conversion, and moreover, show that gonadotropes lose part of their identity when kept in cell culture.
\end{abstract}

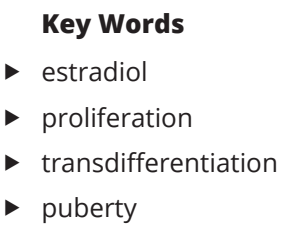

Journal of Endocrinology (2020) 245, 21-37

\section{Introduction}

Gonadotropes are key players in the control of the reproductive function as part of the brain-pituitarygonad axis (Harris 1951, Weltzien et al. 2004). Located in the anterior part of the pituitary, they produce the two gonadotropins: follicle-stimulating hormone (Fsh) and luteinizing hormone (Lh) (Weltzien et al. 2014). Fsh and Lh are mostly produced by the same cell in mammals (Nakane 1970), while the opposite occurs in teleost fish, where Fsh and Lh are produced by two different cell types (Nozaki et al. 1990, Schmitz et al. 2005, Kanda et al. 2011,
Weltzien et al. 2014). Therefore, teleosts seem ideal models to study the development and the different properties of Fsh and Lh cells, as well as the differential regulation of Fsh and Lh synthesis and release (Yaron et al. 2003, Weltzien et al. 2014).

However, despite the general understanding of one hormone one cell type in teleosts, several observations have challenged this hypothesis. Indeed, gonadotropes producing both gonadotropins were found in several teleost species (e.g. Mediterranean yellowtail (c) 2020 The authors Published by Bioscientifica Ltd. Printed in Great Britain

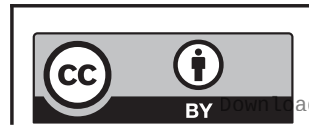

This work is licensed under a Creative Commons Attribution 4.0 International License. 
(Hernandez et al. 2002), zebrafish, tilapia (Golan et al. 2014) and European hake (Candelma et al. 2017)). On the other hand, gonadotropes expressing only one hormone were described in mammals (Childs et al. 1982, Childs 1983). Previous publications have pointed out the fact that Fsh and Lh share the same developmental basis in fish, similar to what is found in mammals (Weltzien et al. 2014) suggesting that Fsh and Lh cells may not be so different from each other in fish, and more similar to the mammalian gonadotropes than we perhaps have anticipated.

Medaka is a powerful teleost model for which several tools have been developed to study its genetics and development (Wittbrodt et al. 2002, Shima \& Mitani 2004). Recently, our team developed two transgenic lines where (i) hrGfpII reporter protein synthesis is controlled by the endogenous medaka $l h b$ promotor using bacterial artificial chromosome (BAC) homologous recombination technology with 103-kb flanking sequence to the $l \mathrm{hb}$ gene (Hildahl et al. 2012) and (ii) DsRed2 synthesis is controlled by the endogenous medaka $f s h b$ promotor using plasmid construction containing 3833 bp of the fshb promoter sequence (Hodne et al. 2019), enabling the study of the gonadotrope cells in more detail.

Previously, several studies conducted on Lh cells in medaka have explored and investigated basic parameters including morphology, ontogeny and regulation of Lh cells. In medaka, Lh cells have been found to participate in the plasticity of the pituitary during puberty through hypertrophy and estrogen-sensitive hyperplasia during puberty (Fontaine et al. 2019). Lh cells have also been shown to make neuron-like projections allowing homotypic networks (Grønlien et al. 2019), to express gnrh receptors (gnrhr), and to respond to gnrh stimuli by increasing their action potential frequency and intracellular calcium concentration (Strandabo et al. 2013, Hodne et al. 2019). However, very little is known about Fsh cells and if and how they contribute to pituitary plasticity during puberty. Therefore, using the recently developed transgenic lines where Fsh and Lh cells can be identified, we investigated gonadotrope plasticity in the medaka pituitary, examining both proliferation and phenotypic plasticity. In addition, we investigated the presence and the origin of bi-hormonal (expressing both Fsh and Lh) cells in medaka.

\section{Materials and methods}

\section{Animal maintenance}

Wild-type (WT, d-rR strain), transgenic $\operatorname{tg}(\operatorname{lh} b$-hrGfpII) (Hildahl et al. 2012), $\operatorname{tg}(f s h b$-DsRed2) and double transgenic $\operatorname{tg}($ lhb-hrGfpII/fshb-DsRed2) (Hodne et al. 2019) medaka (Oryzias latipes) were maintained at $28^{\circ} \mathrm{C}$ on a 14/10 h light/dark cycle in a re-circulating system with reverse osmosis dosed-salt water ( $\mathrm{pH} 7.6$ and conductivity of $800 \mu \mathrm{s})$. Fish were fed three times a day, once with live brine shrimp and twice with dry feed (Gemma; Skretting, Invergordon, UK). Experiments were performed according to the recommendations of the care and welfare of research animals at the Norwegian University of Life Sciences, and under the supervision of authorized investigators. Specifically, the bromodeoxyuridine (BrdU) experiments were approved by the Norwegian Food Safety Authorities (FOTS ID 8596).

\section{Primary pituitary dispersed cell cultures}

Cell cultures were prepared as described in detail in AgerWick et al. (2018). For measuring the volume of DsRed 2 and hrGfp-II expressing cells, four cell cultures were prepared either from 15 adult or due to their smaller size, 25 juvenile pituitaries of $\operatorname{tg}(\mathrm{lh} b$-hrGfpII/fshb-DsRed2) animals from each sex. For quantification of mRNA levels at different time points, cell cultures were prepared by dissociating cells from 25 adult $\operatorname{tg}($ lhb-hrGfpII) females. Cells were then plated in three different wells (each corresponding to a different sampling time point) in a 48 -well plastic plate (Sarstedt, Germany) coated with poly-L-lysine (Sigma), prepared in a laminar flow hood by adding $50 \mu \mathrm{L}$ polyD-lysine, leaving for $1 \mathrm{~min}$ before removing the liquid, washing in $500 \mu \mathrm{L}$ MQ water and leaving the coated wells to dry in UV-light for approximately $30 \mathrm{~min}$.

For investigation of phenotypic conversion, six cell cultures from males and four from females $\operatorname{tg}(\operatorname{lhb}$ hrGfpII/fshb-DsRed2) were prepared. A sub-set of these cell cultures ( $n=2$ from each sex) were treated $4 \mathrm{~h}$ after being plated by adding Gnrh1 (concentration $10 \mu \mathrm{M}$; H-GluHis-trp-ser-His-Gly-Leu-Ser-Pro-Gly-OH trifluorocetate salt, >97\% purity, Bachem AG, Budendorf, Germany) into the medium, a concentration previously shown to induce calcium and electrophysiological responses in Lh and Fsh cells (Strandabo et al. 2013, Ager-Wick et al. 2018, Fontaine et al. 2018, Hodne et al. 2019). Time lapse was recorded as described below for 3 days.

qPCR

(i) fshb mRNA was quantified during development using WT medaka as described in (Hildahl et al. 2012). Briefly, a LightCycler 480 Real-Time PCR system (Roche), with SYBR Green (Roche) was used. Pools of synchronized embryos 
(see Table 2 in Hildahl et al. 2012) were collected in RNAlater for RNA isolation and cDNA synthesis. (ii) gnrhr1b, gnrhr2a, gnrhr $2 b, l h b$ and $f s h b$ mRNA were quantified from cell cultures at three different time points: $1 \mathrm{~h}, 24 \mathrm{~h}$ and $72 \mathrm{~h}$ after plating the dissociated cells. Cells where mechanically detached from the plate by scraping the cells using the pipette in $300 \mu \mathrm{L}$ of TRIzol and further submitted to phenolchloroform RNA extraction using GlycoBlue (Invitrogen) as carrier. Experiments were performed in quadruplicate and triplicate respectively, for proper statistical analysis. Using primers previously used and validated by sequencing the amplicons in Hildahl et al. (2012), Burow et al. (2019) and Hodne et al. (2019) (Table 1), we found that the expression of 16s rRNA (16s) was the most stable across larval development, and the combination of glyceraldehyde 3-phosphate dehydrogenase (gapdh), ribosomal protein L7 (rpl7) and 18s rRNA (18s) was the most stable across time in cell culture according to BestKeeper software (Pfaffl et al. 2004), and thus used to normalize the expression analysis, using an efficiency-corrected relative quantification method (Weltzien et al. 2005).

\section{Steroid treatments and BrdU incubation}

To study effects of sexual steroids on Fsh and Lh cell proliferation, three groups of $\operatorname{tg}(\operatorname{lh} b$-hrGfpII) adult fish (six females and six males) were incubated for 6 days in daily renewed system water containing $100 \mu \mathrm{g} / \mathrm{L}$ of either $17 \beta$-estradiol, testosterone or 11-ketotestosterone (Sigma; diluted in 96\% ethanol), similar to what has been used in (Thompson 2000, El-Alfy \& Schlenk 2002), and shown to significantly increase estradiol plasma level after 7 days of treatment (Thompson 2000). Control fish (six of each sex) were incubated for 6 days with ethanol only (diluted 1:105 in water). The experiment was repeated once. Immediately after steroid treatment, the fish were treated with $1 \mathrm{mM}$ BrdU (Sigma) diluted in water with 15\% DMSO for $8 \mathrm{~h}$.
Fish were then killed, brain and pituitary were collected and fixed in $4 \%$ paraformaldehyde overnight, and gradually dehydrated and stored in 100\% methanol until use.

\section{Immunofluorescence}

To investigate cell proliferation, tissues were labelled for BrdU, PCNA as well as for Fsh $\beta$ with immunofluorescence (IF), as previously described (Fontaine et al. 2013, Burow et al. 2019, Fontaine et al. 2019). Briefly, IF was performed on free-floating sections obtained after the tissues were included in 3\% agarose and parasagittaly sectioned (60 $\mu \mathrm{m})$ with a vibratom (Leica). Because the fluorescence of the endogenous DsRed2 is quenched with the epitope retrieval treatments required for BrdU and PCNA staining, $\operatorname{tg}(\operatorname{lh} b$-hrGfpII) animals were used and IF for Fsh $\beta$, with a custom-made polyclonal rabbit anti-medakaFsh $\beta$ (1:500 (Burow et al. 2019)) was performed. Nuclei were stained with DAPI (1:1000; 4',6-diamidino-2-phenylindole dihydrochloride; Sigma).

To investigate $\operatorname{Lh} \beta$ protein production in cell culture, we prepared three cell cultures from female $\operatorname{tg}(f s h b$-DsRed2) and three cell cultures from female $\operatorname{tg}(\operatorname{lh} b$-hrGfpII/fshbDsRed2). Cells were treated with Gnrh1 as described earlier. To investigate whether Fsh cells possess $\operatorname{Lh} \beta$ protein right after dissociation, one cell culture from $\operatorname{tg}(f s h b$-DsRed2) line was fixed $1 \mathrm{~h}$ after dissociation. The other cell cultures were incubated $72 \mathrm{~h}$ with GnRH. Cells were fixed with $4 \%$ paraformaldehyde (diluted in phosphate saline buffer, PBS) for $15 \mathrm{~min}$ at room temperature (RT) and washed with PBS. Then, cells were incubated 15 min with $0.3 \%$ triton (Sigma) diluted in PBS and washed again with PBS. Cells were then incubated in blocking (10\% normal goat serum diluted in PBS) before being incubated with the previously validated antibody anti rabbit anti-medakaLh $\beta$ (1:1000 in blocking solution (Burow et al. 2019)) overnight at $4^{\circ} \mathrm{C}$. As control, one of the three cell culture was not receiving

Table 1 List of primers used for qPCR.

\begin{tabular}{l}
\hline Gene name \\
\hline $16 s$ \\
rpl-7 \\
$\beta$-actin \\
fshb \\
Ihb \\
gnrhr1b \\
gnrhr2a \\
gnrhr2b \\
$18 s$ \\
gapdh
\end{tabular}

\begin{tabular}{l}
\hline Forward sequence 5'-3' \\
\hline CGATCAACGGACCGAGTTACC \\
TGCTTTGGTGGAGAAAGCTC \\
ACCCTGTCCTGCTCACTGAA \\
GACGGTGCTACCATGAGGAT \\
CCACTGCCTTACCAAGGACC \\
TCCTGCTACACATCCACCAG \\
GGGCGATGAGTGTGATCCTC \\
TTGAGATATCAAGCCGCATC \\
CCTGCGGCTTAATTTGACTC \\
CCTCCATCTTTGATGCTGGT
\end{tabular}

\begin{tabular}{l}
\hline Reverse sequence $\mathbf{5}^{\prime} \mathbf{- 3}$ ' \\
\hline AATAGCGGCTGCACCATTAGG \\
TGGCAGGCTTGAAGTTCTTT \\
GCAGGGCTGTTGAAAGTCTC \\
TCCCCACTGCAGATCTTTTC \\
AGGAAGCTCAAATGTCTTGTAG \\
GCCTTTGGGATGATGTCTGT \\
CCCGAGTGGCACATTGAGT \\
GAGTCCTCATCCGAGCTTTG \\
AACTAAGAACGGCCATGCAC \\
ACGGTTGCTGTAGCCAAACT
\end{tabular}

\begin{tabular}{c}
\hline Amplicon length \\
\hline 119 \\
98 \\
92 \\
73 \\
100 \\
88 \\
96 \\
99 \\
118 \\
75 \\
\hline
\end{tabular}

\begin{tabular}{c}
\hline qPCR efficiency \\
\hline 2.05 \\
2.03 \\
2.07 \\
2.03 \\
2.00 \\
1.99 \\
1.99 \\
2.02 \\
2.02 \\
2.01
\end{tabular}


the primary antibody. Colour revelation was performed by washing the cells with PBS and then incubating them $1 \mathrm{~h}$ at RT with a secondary antibody conjugated to either Alexa-488 for $\operatorname{tg}(f s h b$-DsRed2) cell cultures or Alexa-647 for $\operatorname{tg}(\mathrm{l} h b$-hrGfpII/fshb-DsRed2) cell cultures (Invitrogen).

\section{Fluorescence in situ hybridization (FISH)}

FISH was performed as described in Fontaine et al. (2013). Briefly, six adult fish from each sex from the $\operatorname{tg}(\mathrm{lhb}$-hrGfpII) line were killed with ice cold water, and brain and pituitary were collected and fixed in $4 \%$ paraformaldehyde. Tissues were then gradually dehydrated and stored in 100\% methanol until use. Tissue were then rehydrated and sectioned parasagittally $(60 \mu \mathrm{m})$ with a vibratome (Leica). Free-floating sections were hybridized with Cyp19a1bdigoxigenin-tagged (DIG) and $f$ shb-fluorescein-tagged (FITC) riboprobes (Okubo et al. 2011, Fontaine et al. 2019) for $18 \mathrm{~h}$ at $55^{\circ} \mathrm{C}$. Colour revelation was performed with sheep anti-DIG, and anti-FITC conjugated with peroxidase (1:250; Roche), together with TAMRA-conjugated and Cy5-conjugated tyramides for FISH (Roche). Nuclei were stained with DAPI (1:1000; Sigma).

\section{Imaging}

For imaging of the $\operatorname{tg}(\operatorname{lh} b$-hrGfpII/fshb-DsRed2) line during ontogeny (8-10 unsexed fish per stage) or for investigating the presence of bi-hormonal cells (12 unsexed fish per stage), no treatments where needed and endogenous hrGfpII together with DsRed2 were directly visualized. For all, vibratome slices were mounted between slide and coverslip with antifade mounting medium Vectashield (Vector, UK), and spacers were added between the slice and the coverslip when mounting whole pituitaries. Time-lapse recordings of dissociated pituitary cells were performed in a humid chamber at $26^{\circ} \mathrm{C}$ with $1 \% \mathrm{CO}_{2}$ (Ager-Wick et al. 2018). All confocal images were acquired using a LSM710 microscope (Zeiss) with $10 \times, 25 \times, 40 \times$ or $63 \times$ (respectively N.A. $0.3,0.8,1.2$ or 1.4) objectives. Channels were acquired sequentially to avoid signal crossover between filters. Z-projections from confocal image stacks were obtained using Fiji software (v2.0.0 (Schindelin et al. 2012)). 3D reconstruction was built using 3D-viewer plugin (Schmid et al. 2010).

\section{Calcium imaging and Gnrh1 stimulation}

Calcium imaging and Gnrh1 stimulation were performed as described in (Hodne et al. 2019). Briefly, a total of three dishes of dissociated adult female $\operatorname{tg}(f s h b$-DsRed2) pituitary cells were used. Following 3 days in culture, the cells were gently washed in artificial BSA-free extracellular solution (ECS: in $\mathrm{mM}: \mathrm{NaCl} 134, \mathrm{KCl} 2.9, \mathrm{MgCl}_{2} 1.2$, HEPES 10, and glucose 4.5, pH 7.75 and 290 mosmol), then incubated in $5 \mu \mathrm{M}$ Fluo4-AM dye (ThermoFisher Scientific) for $30 \mathrm{~min}$ before incubation in ECS added $0.1 \%$ BSA for $20 \mathrm{~min}$. In total, 29 cells were stimulated with Gnrh1 (10 $\mu \mathrm{M}$ dissolved in ECS with $0.1 \%$ BSA) using puff ejection (20 $\mathrm{kPa}$ through a $2 \mathrm{M} \Omega$ glass pipette, $30-40 \mu \mathrm{m}$ from the target cell). Cells were imaged using a sCMOS camera (optiMOS, QImaging, British Columbia, Canada) with exposure time 50 to $80 \mathrm{~ms}$ and sampling frequency $0.5 \mathrm{~Hz}$ using $\mu$ Manager software, v1.4 (Edelstein et al. 2014). Relative fluorescence intensity was calculated after background subtraction as changes in fluorescence (F) divided by the average intensity of the first 15 frames (F0). Data analysis was performed using Fiji software.

\section{Counting and measurements}

Counting of Fsh cells was performed blindly using Cell Profiler software (v2.1.0 (Carpenter et al. 2006)) as described in Fontaine et al. (2019), from eight to nine animals from each sex and stage. Double-labeled cells (BrdU/hrGfpII or BrdU/DsRed2) after steroid and BrdU treatments were manually counted using Fiji software and cell-counter plugin. Cell volume was measured by recording Z-stacks of dissociated cells a few minutes after being plated and using Fiji software and the voxel counter plugin for 9-36 cells per group. The fluorescence intensity in the mean region of interest (ROI) was measured with Fiji on five different cells from two different cell cultures using $10 \times$ objective. For good clarity of the figure only three cells were kept.

\section{Statistics}

Data were analyzed using GraphPad Prism (v8.0), tested for normality using the Shapiro-Wilk normality test. Significant difference between groups was set at $P<0.05$, and non-parametric tests were used when data were not normally distributed. See figure legends for details.

\section{Results}

\section{Ontogeny of Fsh cells in the pituitary}

qPCR (Fig. 1A) shows that relative expression of $f s h b$ mRNA in the embryo starts to increase after $72 \mathrm{~h}$ post fertilization

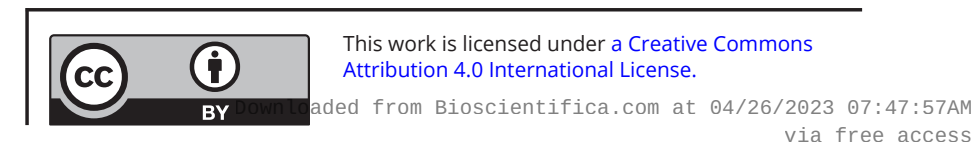


A
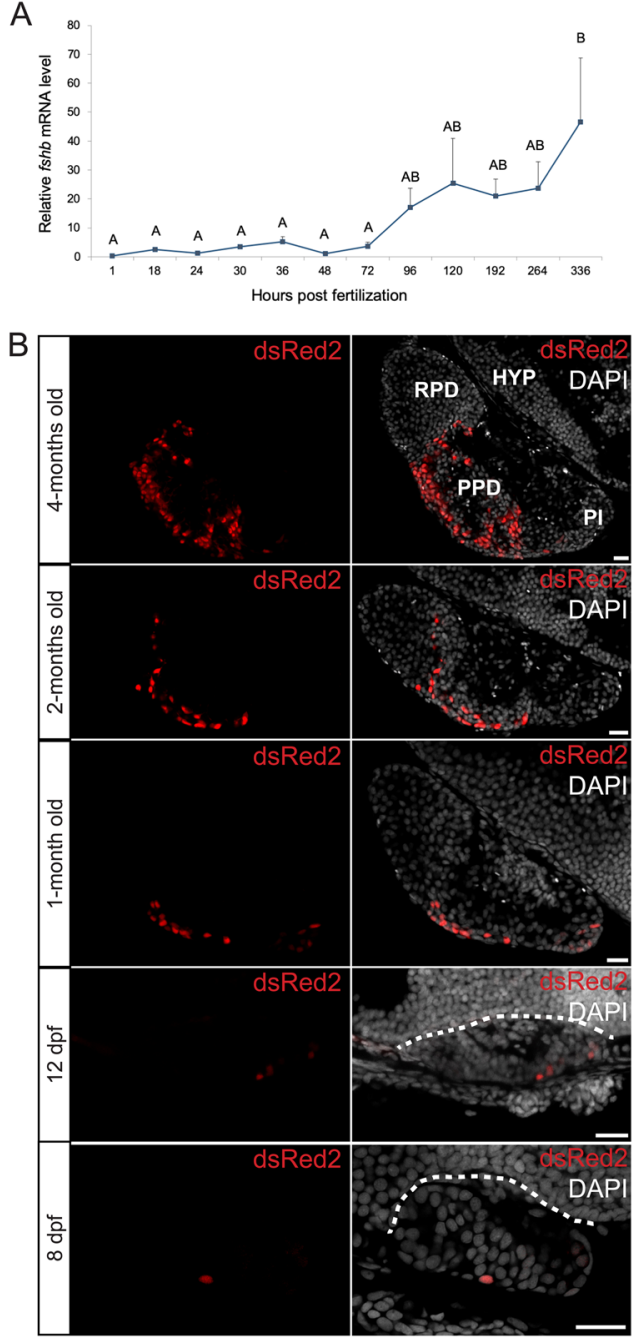

C

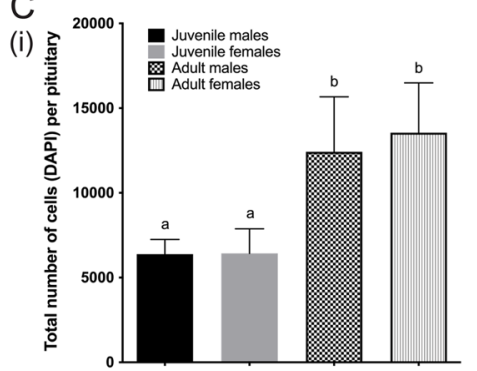

(ii)

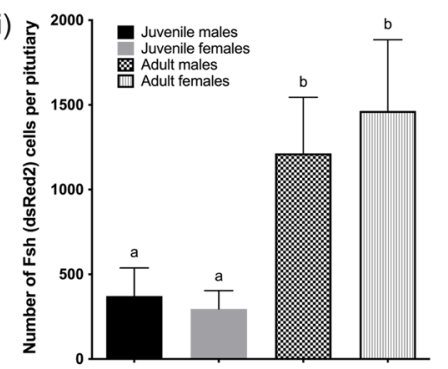

(iii)

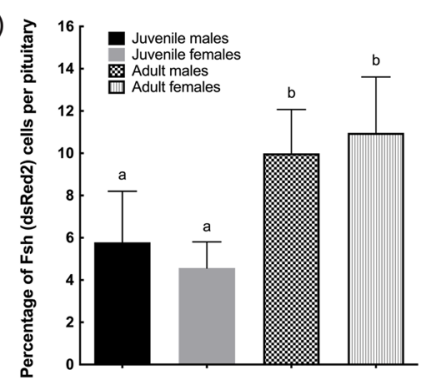

Figure 1

(A) Relative $f s h b$ mRNA levels during early development in pooled medaka larvae by quantitative polymerase chain reaction (qPCR) analysis. fshb gene expression was normalized to $16 s$ gene expression using an efficiency adjusted relative quantification method. Data are presented as mean relative expression + S.E.M., $n=4$. Data were tested for normal distribution with the Shapiro-Wilk normality test, and relative mRNA levels were significantly different $(P<0.05)$ using one-way ANOVA followed by a TukeyKramer HSD post hoc analysis when letters are different (A and B). (B) Ontogeny of DsRed2 producing cells in the $\operatorname{tg}(f s h b$-DsRed2) line. Parasagittal sections of the brain and the pituitary for fish from 1-month old up to 4-months old, and of the whole embryo for younger stages, without (left panels) or with nuclear (DAPI) staining (right panels). Dotted lines delimit the dorsal part of the pituitary. Scale bars: $20 \mu \mathrm{m}$. (C) Cell counting for the four different groups of fish: juvenile males $(n=9)$ and females $(n=9)$, and adult males $(n=8)$ and females ( $n=9$ ). (i) Mean (+s.D.) of the total number of cells in the pituitary. (ii) Mean (+s.D.) of the number of DsRed2 cells in the pituitary. (iii) Mean (+S.D.) of the percentage of DsRed2 cells related to the total number of cells in the pituitary. For each graph, data were tested for normal distribution with the Shapiro-Wilk normality test, and one-way ANOVA with Tukey's multiple comparison test revealed significant differences $(P<0.05)$ when letters are different (a and b). (hpf; 3 days). It becomes significantly different from the early time points after $336 \mathrm{hpf}$ (14 days). To investigate at which time the first Fsh cells appear, we looked at the endogenous DsRed2 (Fig. 1B) fluorescence starting with adult fish, back to younger stages in the $\operatorname{tg}(f s h b$-DsRed2) line. First, we did not observe any DsRed2 cells outside of the pituitary at all studied stages. Second, we found the first cells to arise around 8 days post fertilization (dpf), with a single DsRed 2 cell observed in two of eight studied embryos at this stage. Third, we observed an increasing number of DsRed2 between each studied stage along development.

Therefore, we counted the number of DsRed 2 cells in the pituitary as well as the total number of cells using the nuclear DAPI staining, and calculated the percentage of DsRed2 cells in the pituitary (Fig. 1C), in juveniles (2-month old) and adults (6-month old) in both sex. While the number of cells in the pituitary increased significantly between juvenile and adult stages, there was no significant differences between sex at any stage.
The same observation was made for the number of DsRed2 cells and the percentage of DsRed2 cells in the pituitary. In adults however, there was a noticeable tendency for higher numbers of cells and DsRed2-positive cells in females as compared to in males.

\section{Proliferation of Fsh cells}

We then looked for the origin of the new DsRed2-positive cells. IF for proliferating cell nuclear antigen (PCNA) together with Fsh $\beta$ showed some cells expressing both proteins (Fig. 2A, B and C). In addition, IF for BrdU together with Fsh $\beta$ on fish incubated for $8 \mathrm{~h}$ in BrdU solution revealed that some Fsh $\beta$-producing cells had integrated $\mathrm{BrdU}$, therefore confirming active cell division (Fig. 2D, E and F).

We then investigated the effect of sex steroids on gonadotrope cell proliferation. Unfortunately, some of the treated fish were not Gfp positive and some HCL treatment to unmask Fsh $\beta$ epitope did not work, 

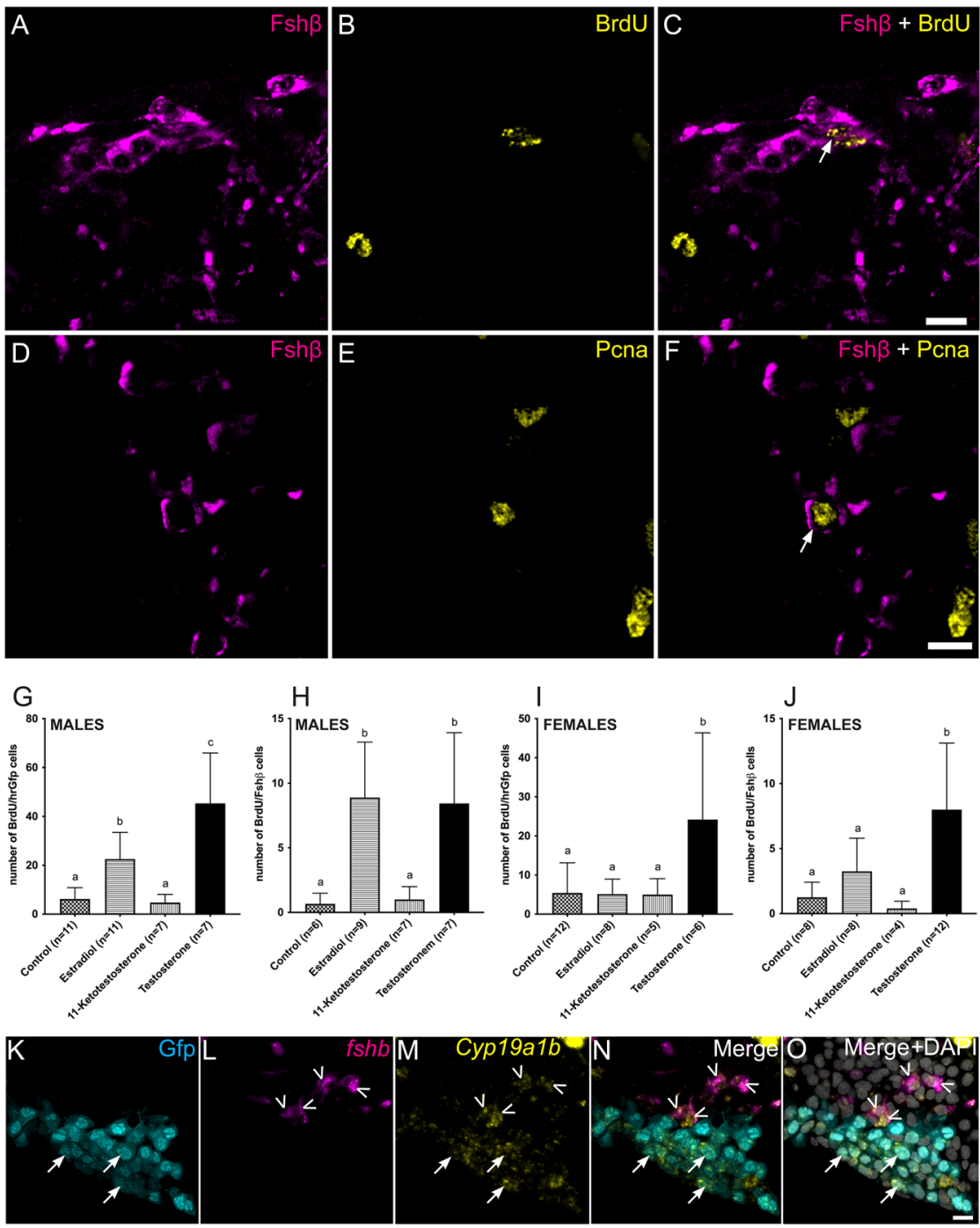

Figure 2

(A, B and C) Confocal plan images of a parasagittal section from a $\operatorname{tg}(/ h b$-hrGfpll) adult female medaka pituitary incubated in BrdU for $8 \mathrm{~h}$ and labeled by immunofluorescence for $F$ sh $\beta$ (magenta) and BrdU (yellow). (D, E and F) Confocal plane images of a parasagittal section from an adult WT female medaka pituitary labeled by immunofluorescence for Fsh $\beta$ (magenta) and proliferating cell nuclear antigen (PCNA; yellow). Scale bars: $10 \mu \mathrm{m}$. (G, H, I and J) Graphics presenting the mean (+S.D.) number of double labelled cells, BrdU/hrGfpll, using BrdU immunofluorescence and endogenous hrGfpll fluorescence ( $G$ and I) or BrdU/Fsh $\beta$ using bi-color Fsh $\beta$ and $B r d U$ immunofluorescence $(H$ and $J)$ in the pituitary from adult medaka males ( $\mathrm{G}$ and $\mathrm{H}$ ) and females ( $($ and $\mathrm{J})$. Fish were treated for $8 \mathrm{~h}$ in BrdU after 6 days treatment in either estradiol, 11-ketotestosterone, testosterone or ethanol (control). ' $n$ ' represents the number of individual fish analyzed. Data were found to not follow a normal distribution according to the Shapiro-Wilk normality test, thus non-parametric test was used. For each graph, Kruskal-Wallis test followed by Dunn's multiple comparison test revealed significant differences $(P<0.05)$ when letters are different ( $a, b$ and $c)$. ( $K, L, M, N$ and O) Multi-color fluorescent in situ hybridization for fshb and aromatase (cyp19a1b) with nuclear staining (DAPI) in the $\operatorname{tg}(/ h b$-hrGfplI) adult female pituitary. Arrows show the Lh (Gfp) cells, and arrowheads the $f s h b$-expressing cells which also express cyp19a1b. Scale bar: $10 \mu \mathrm{m}$.

leading to reduced number of samples in some of the groups (see ' $n$ ' in Fig. 2G, H, I and J). Nevertheless, steroid treatments before BrdU incubation and labelling by IF revealed that, contrary to 11-ketotestosterone (11-KT), both estradiol (E2) and testosterone were able to significantly increase the number of both BrdU/hrGfpII and $\operatorname{BrdU} / \mathrm{Fsh} \beta$ cells in male pituitaries compared to control. In females, testosterone was able to increase the number of BrdU/Fsh $\beta$ and BrdU/hrGfpII cells compared to control, although the difference was only significant for BrdU/Fsh $\beta$. In contrast, other treatments did not affect the number of BrdU/hrGfpII or BrdU/Fsh $\beta$ cells in females.

Finally, we investigated the expression of aromatase (Cyp19a1b) in fshb-expressing cells and Gfp cells using multicolor FISH in both sexes. We observed in both males and females without noticeable differences, the expression of Cyp19a1b in both Lh (arrows) and Fsh (arrowheads, Fig. $2 \mathrm{~K}, \mathrm{~L}, \mathrm{M}, \mathrm{N}$ and $\mathrm{O}$ ).

\section{Distribution of Lh and Fsh cells in the pituitary}

Based on observations in the double transgenic line (lhb-hrGfpII/fshb-DsRed2), hrGfpII and DsRed2-positive cells are distributed in the median part of the pituitary in adult fish (Fig. 3). This becomes even more clear when looking at the distribution in a 3D reconstituted image of the pituitary (Juveniles: Supplementary Movies 1 and 2; adults: Supplementary Movies 3 and 4, see section on supplementary materials given at the end of this article). We did not observe any difference between sex (data in males not shown); however, we could clearly see that in adults, hrGfpII cells are situated along the ventral and lateral surface of the pituitary while DsRed2 are located more internally. While hrGfpII cells to a large extent are clustered, DsRed2 cells seem more individualized and spread out. In juveniles, some of the DsRed2 cells were closer to the surface, some even touching the ventral

This work is licensed under a Creative Commons Attribution 4.0 International License. ded from Bioscientifica.com at 04/26/2023 07:47:57AM 


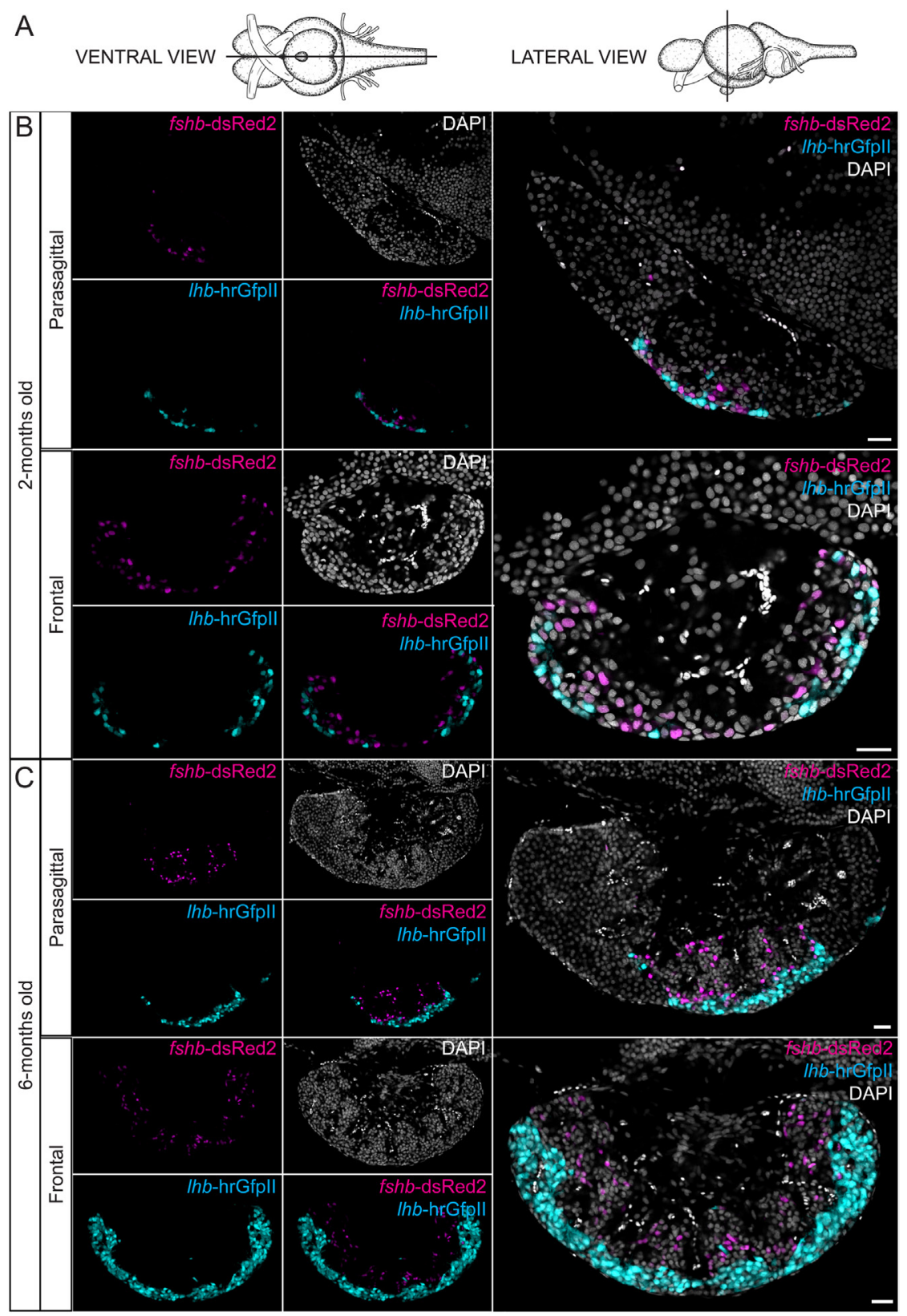

\section{Figure 3}

(A) Schemas presenting the position of the sections made in the brain and pituitary used for the following images, from the ventral and ventral point of view providing respectively parasagittal and frontal sections. (B) Confocal plan images of the endogenous fluorescence from 2-months old and 6-months old females $\operatorname{tg}(/ h b$-hrGfpll/fshbDsRed2) medaka brain and pituitary, in parasagittal and frontal sections. Sections are shown without or with nuclear (DAPI) staining. Scale bars: $20 \mu \mathrm{m}$.

and lateral surface of the pituitary, while this was never observed in adults where Lh cells cover the entire ventral and lateral surface.

Interestingly, a few cells were positive for both hrGfpII and DsRed2 in 6-, 2- and 1-month-old fish (Fig. 4A). Such co-expression was also shown in WT animals using FISH for $l h b$ and $f s h b$ mRNA (Fig. 4B). However, cells expressing both reporter proteins were never observed in $14 \mathrm{dpf}$ larvae ( $n=12$ larvae), at which time the first Lh cells arise in the pituitary. At this developmental stage, a few cells were weakly labelled either hrGfpII or DsRed2, but never in the same cell (Fig. 4A). (c) 2020 The authors

https://joe.bioscientifica.com https://doi.org/10.1530/JOE-19-0405

\section{Morphology of Fsh and Lh cells}

Using the double transgenic line (lhb-hrGfpII/fshbDsRed2), we investigated cell morphology. Measuring the volume of both hrGfpII and DsRed2-positive cells in dissociated pituitary cell cultures from juveniles and adults (Fig. 5A), we observed a volume increase from juvenile to adult stages in both cell types. Interestingly, the cell volume is similar for hrGfpII and DsRed2-positive cells at both analyzed life stages.

In addition, we observed that both in cell culture as well as in fixed tissue slices, hrGfpII and DsRed2-positive 

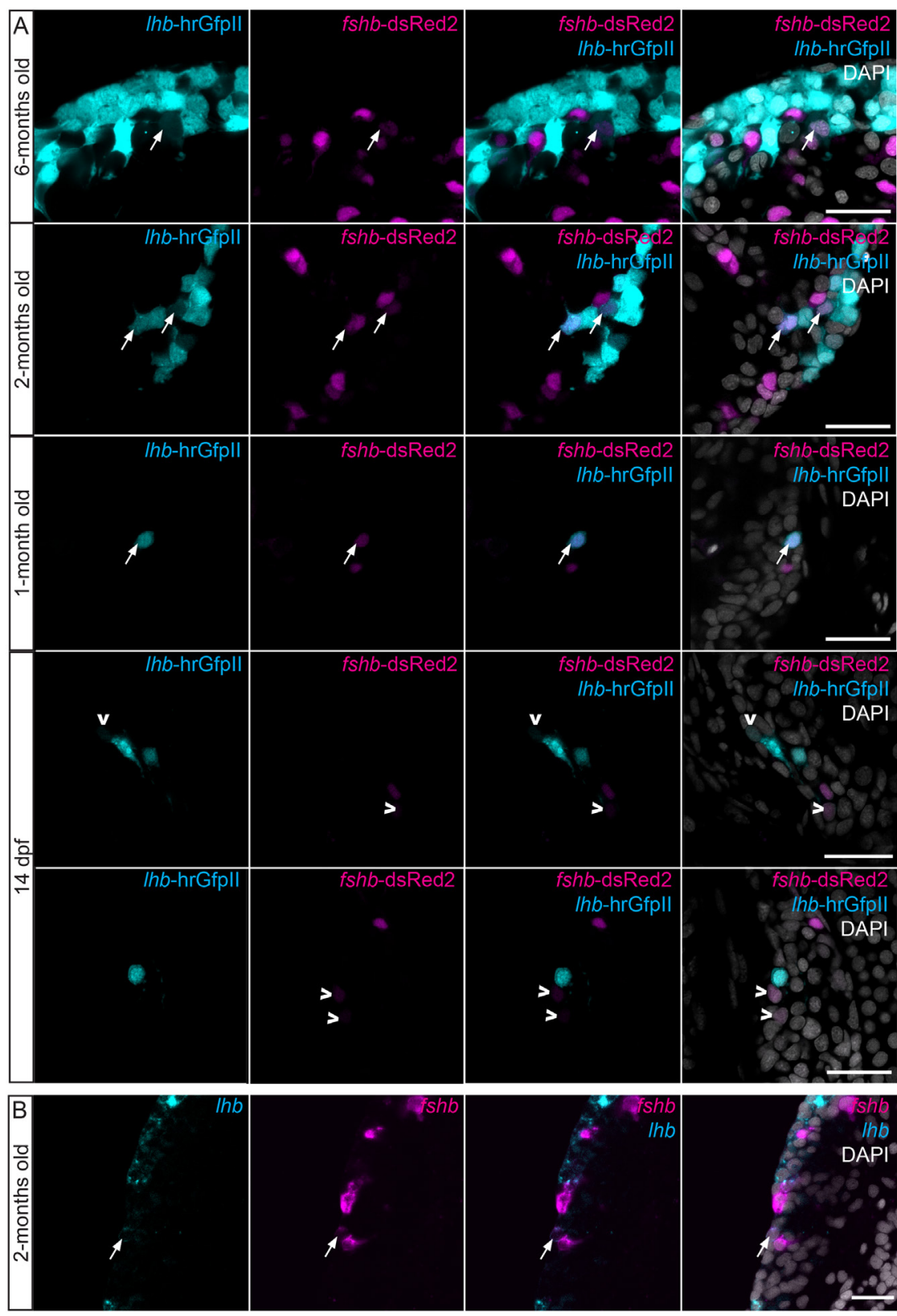

cells show seemingly similar long extensions from the cell body (Fig. 5B, C and D). In dissociated cell culture, they use these extensions to make connections between them (homotypic and heterotypic networks; Fig. 5E, F, G, H and Supplementary Movie 5). They also use these extensions for clustering (Fig. 5I, J, K and Supplementary Movie 5).

\section{Phenotypic conversion of Fsh cells into Lh cells in medaka primary pituitary cell culture}

Recording time lapse images of dissociated primary pituitary cell culture from the double transgenic line

\begin{tabular}{|lr}
\hline https://joe.bioscientifica.com & @ 2020 The authors \\
https://doi.org/10.1530/JOE-19-0405 & Published by Bioscientifica Ltd. \\
Printed in Great Britain
\end{tabular}

\section{Figure 4}

(A) Confocal plan images from the endogenous fluorescence in parasagittal sections from

6-months old, 2-months old, 1 month old and 14 dpf unsexed $\operatorname{tg}(/ h b$-hrGfpll/fshb-DsRed2) medaka brain and pituitary. (B) Confocal plan images of a parasagittal section from the brain and pituitary of a 2-months old WT fish labeled by multi-color FISH for Ihb and $f s h b$ mRNA. Cells expressing both hrGfpll and DsRed2 (A) or Ihb and fshb (B) are shown with white arrows while cells showing weak expression of DsRed2 or hrGfpll are shown with white arrow heads (A). Scale bars: $20 \mu \mathrm{m}$.
(lhb-hrGfpII/fshb-DsRed2), we observed that some cells which were not expressing hrGfpII at the beginning were able to start to produce it with time (Fig. 6A, B and Supplementary Movie 6). Most of the cells starting to express hrGfpII in the culture where DsRed2 positive and some of them start to produce hrGfpII already after $15 \mathrm{~h}$ in cell culture. In addition, while we observed an increase of hrGfpII fluorescence over time, we did not observe any decrease of DsRed2 fluorescence in these cells (Fig. 6B). We also found that adding Gnrh1 in the medium, significantly increased the number of DsRed2 positive cells starting to produce hrGfpII (Fig. 6C). Interestingly, we also observed cells that initially were not labelled 

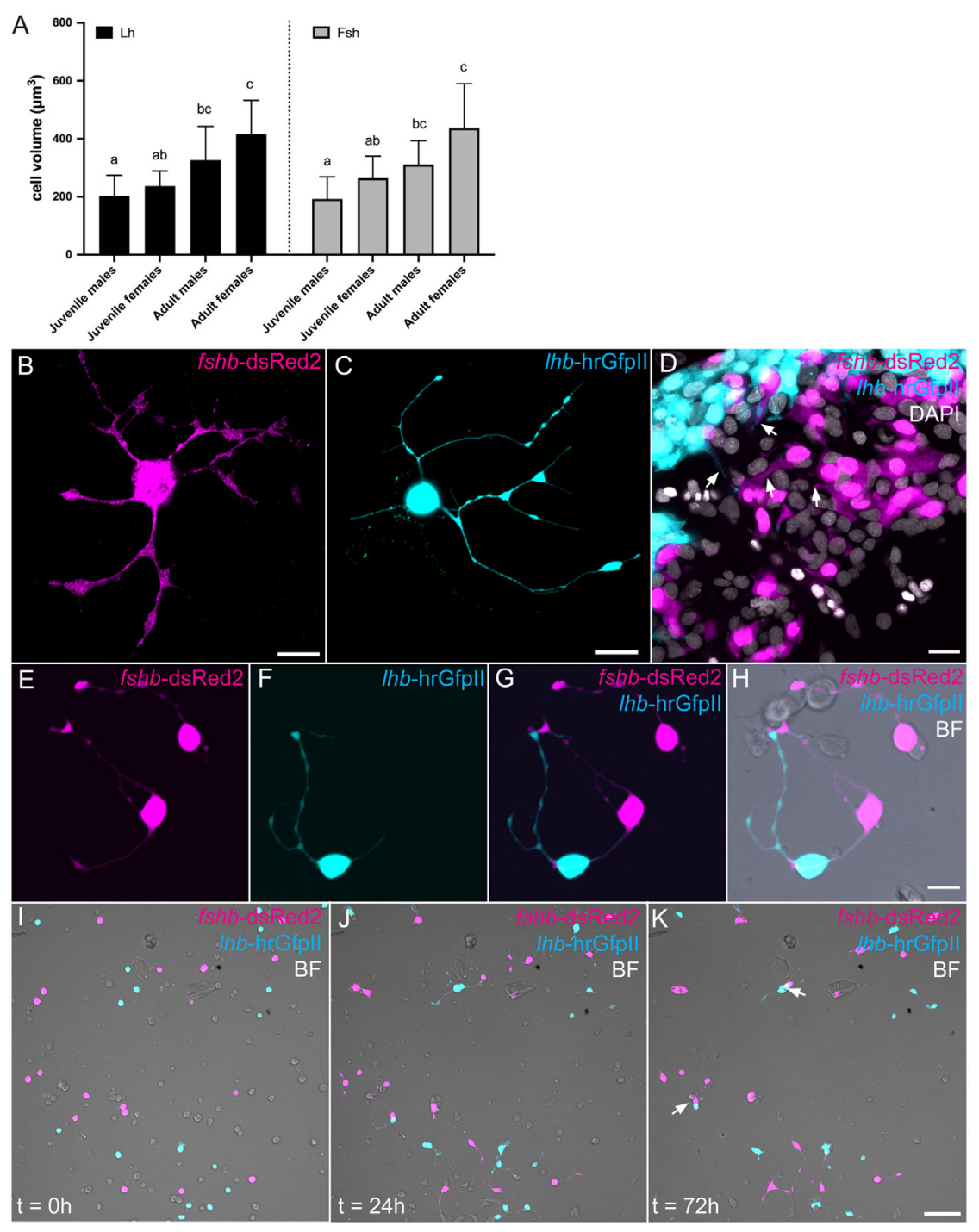

starting to express hrGfpII, but we never observed any hrGfpII expressing cell starting to produce DsRed2.

Then, we performed IF for $\operatorname{Lh} \beta$ to investigate whether the Fsh (DsRed2-positive) cells observed to become Gfppositive in culture where also producing the $\operatorname{Lh} \beta$ protein. First, without the use of the primary antibody, we could not observe any labelling. This confirms the specificity of the secondary antibodies used in cell culture. Second, using the $\operatorname{tg}(f s h b$-DsRed2) line, we could not observe any DsRed2-positive cells labelled for $\operatorname{Lh} \beta 1 \mathrm{~h}$ after dissociation, while several could be observed after $72 \mathrm{~h}$ incubation with Gnrh1 (Fig. 6D). Third, with the double transgenic line (llhbhrGfpII/fshb-DsRed2) we found that some cells, both Gfpand DsRed2-positives, were labelled for $\operatorname{Lh} \beta$ while we could not observe any DsRed2-only cell labelled for Lh $\beta$ (Fig. 6E).

\section{Figure 5}

(A) Graphic showing the calculated cell volume of Lh (hrGfpII) or Fsh (DsRed2) cells in cell culture from $\operatorname{tg}(/ h b$-hrGfpll/fshb-DsRed2) animals, just after cells were dissociated and plated. Cell volume was measured in cells from juvenile males ( $n=10$ cells) and females ( $n=9$ cells) as well as in adult males ( $n=13$ cells) and females ( $n=23$ cells). Data were log-transformed and tested for normal distribution with the Shapiro-Wilk normality test. Two-way ANOVA with Tukey's multiple comparison test revealed significant differences $(P<0.05)$ when letters are different $(a, b$, and $c)$. (B and $C$ ) Confocal plan image from a dsRed positive (Fsh) and hrGfpll (Lh) cell respectively, in cell culture for $24 \mathrm{~h}$. (D) Confocal plan image from a parasagittal section of a pituitary from adult $\operatorname{tg}(/ h b$-hrGfpll/fshb-DsRed2) female with nuclear (DAPI) staining. Arrows show the extensions of the cells in the tissue. (E, F, G and H) Confocal plan images from pituitary cell culture from tg $(/ h b$ hrGfpll/fshb-DsRed2) adult females, $24 \mathrm{~h}$ after dissociation showing heterotypic network between a dsRed positive (Fsh) and hrGfpll (Lh) cell as well as other unknown cell types revealed by the brightfield (BF) image. Scale bars: $10 \mu \mathrm{m}$. (I, $\mathrm{J}$ and K) Time lapse image of a pituitary cell culture from tg(/hb-hrGfpll/fshb-DsRed2) adult females showing clustering of dsRed-positive (Fsh) and hrGfpll (Lh) cells as shown by the arrows. Scale bar: $50 \mu \mathrm{m}$.

\section{Activity of Fsh cells upon Gnrh stimulation in medaka primary pituitary cell culture}

In our previous study of adult female medaka, we demonstrated that Fsh cells lack Gnrh receptors in tissue sections and do not show calcium or electrophysiological responses upon Gnrh stimulation when investigating the cells shortly after dissociation (Hodne et al. 2019). Using dissociated primary pituitary cell cultures from adult female $\operatorname{tg}(f s h b$ :DsRed2) line and the calcium imaging technique, we observed that 3 days after plating, 55\% of the DsRed2 expressing cells show a transient elevation in cytosolic calcium with a latency of 2-5 s upon Gnrh1 stimulation (Fig. 7). The response usually lasted between 20 and 60 s before returning to baseline values.

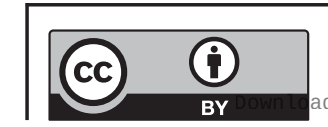

This work is licensed under a Creative Commons Attribution 4.0 International License. 


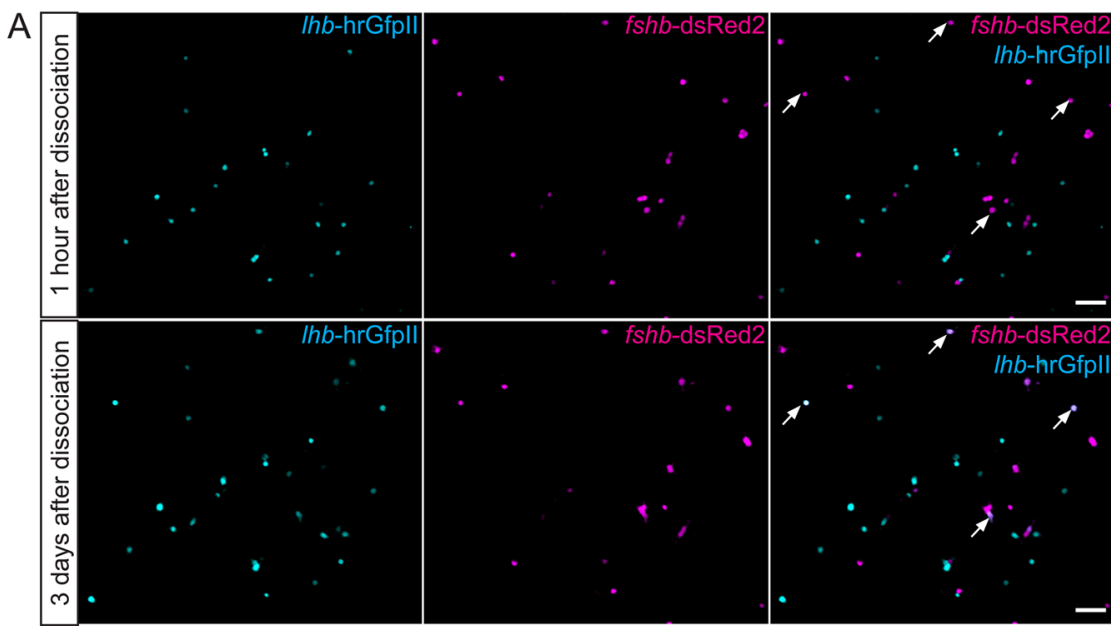

B
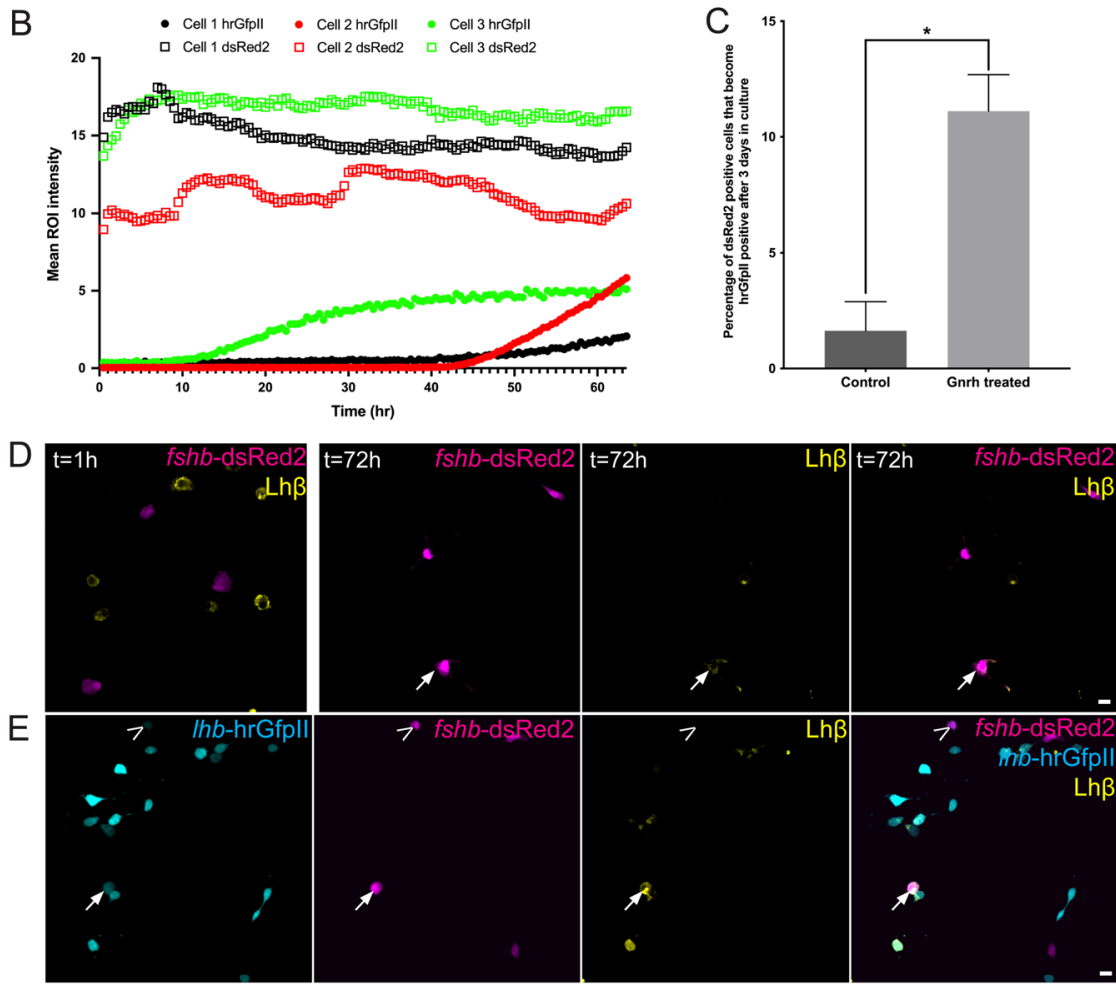

\section{Figure 6}

(A) Confocal plan images of a pituitary cell culture from $\operatorname{tg}(/ h b$-hrGfpll/fshb-DsRed2) adult males 1 hour (top panels) and 3 days (bottom panels) after dissociation. Arrows show DsRed2-positive cells that are becoming hrGfpll-positive cells during the 3 days. (B) Graphic presenting the mean fluorescent ROI intensity for hrGfpll and DsRed2 from three different cells over time, from two different cell cultures imaged with a 10x objective. (C) Graphic showing the mean (+S.E.M.) of the percentage of DsRed2-positive cells that have started to produce hrGfpll after 3 days in cell culture with Gnrh1 ( $n=4$ cell cultures from two males and two females) or without (control $n=6$ cell cultures from four males and two females). Cell cultures from different sexes were pooled as they presented similar results for each treatment. Data were found to not follow a normal distribution according to the Shapiro-Wilk normality test, thus the non-parametric Mann-Whitney test was used to investigate significant difference in the proportion of Fsh (DsRed2) cells changing phenotype with or without Gnrh1 stimulation. (D) Confocal plan on cell cultures from adult tg(fshb-DsRed2) females, 1 or $72 \mathrm{~h}$ after dissociation and incubation with Gnrh1, and labelled for Lh $\beta$ by immunofluorescence. The arrow shows a DsRed2positice cell labeled for Lh $\beta$. (E) Confocal plan on cell cultures from adult tg(/hb-hrGfplI/fshb-

DsRed2) females, incubated with Gnrh1 for 3 days and labelled for Lh $\beta$ by immunofluorescence. The arrow shows a cell producing both Gfp and DsRed 2 and labeled for $\operatorname{Lh} \beta$ while the arrowhead shows another cell producing both Gfp and DsRed2 but not labeled for Lh $\beta$. Scale bars: $10 \mu \mathrm{m}$.

\section{Temporal gene expression in primary medaka pituitary cell culture}

We analyzed gene expression over time in cell culture of $l h b, f s h b$ and the three Gnrhr found in the medaka pituitary (gnrhr1b, gnrhr2a and gnrhr2b) according to (Hodne et al. 2019). Three time points were studied (Fig. 8), $1 \mathrm{~h}, 24 \mathrm{~h}$ and $72 \mathrm{~h}$ after the dissociated cells were plated. We observed a significant reduction in $f s h b$ expression already after $24 \mathrm{~h}$. In contrast, no significant change in expression was observed for $l h b$, gnrhr1b, gnrhr $2 a$ and gnrhr $2 b$ over time. Printed in Great Britain

\section{Discussion}

Lh and Fsh are key players in the BPG axis, controlling reproductive function. While medaka Lh cells have been well described (Hildahl et al. 2012, Fontaine et al. 2019), little is known about Fsh cells and the population they form in the medaka pituitary. In general, less is known about Fsh cells than for Lh cells in teleost fish. In this study, we used the recently developed and validated medaka transgenic lines allowing for the visualization and localization of Fsh-producing (DsRed2) and Lh-producing (hrGfp) cells (Hodne et al. 2019), referred to as Lh and Fsh cells, 


\section{Journal of Endocrinology}

A

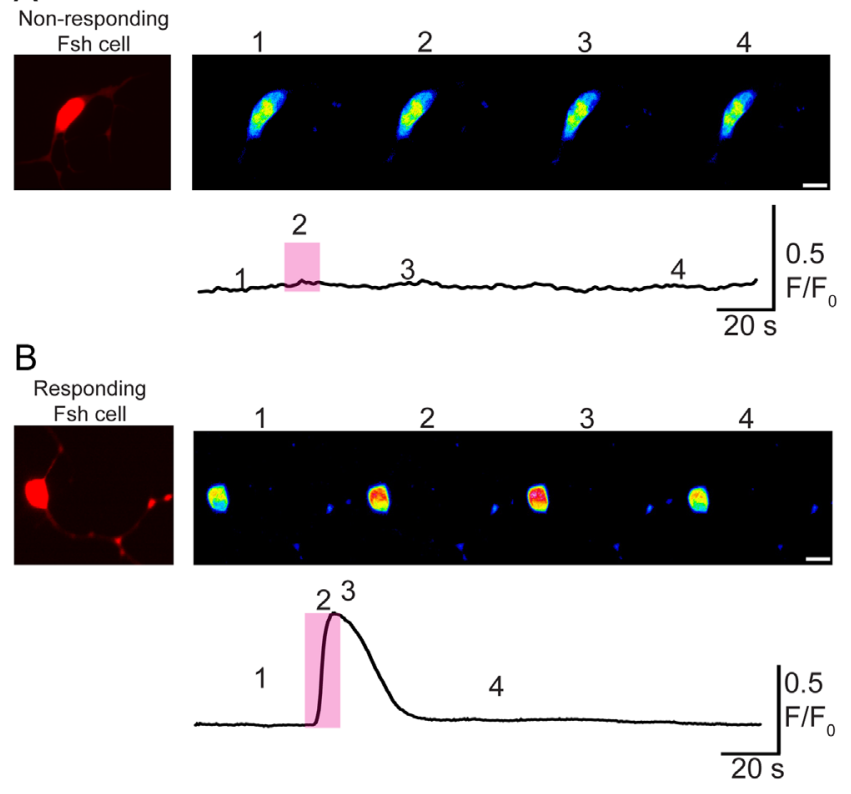

Figure 7

Cytosolic calcium measurements in Fsh cells following $1 \mu \mathrm{M}$ Gnrh1 stimulation using 3 days cultivated dissociated pituitary cells from adult female $\operatorname{tg}($ fshb-DsRed2) medaka. In total 16 of 29 Fsh cells (55\%) responded to Gnrh1. Recording of the fluorescence intensity after stimulation with Gnrh1 in a (A) non-responding Fsh cell and (B) responding Fsh cell. (A and B) Upper micrographs represent four images from a time lapse of an Fsh cell following Gnrh stimulation (pink shaded rectangle). Below, the corresponding trace were each number (1-4) represents the timepoints of the selected pictures above. Scale bars on images: $10 \mu \mathrm{m}$.

following the definition of endocrine cells used by Pogoda $\&$ Hammerschmidt (2007).

We first studied the ontogeny of Fsh cells and demonstrated that while a significant increase of the $f s h b$ mRNA relative amount cannot be observed before $14 \mathrm{dpf}$, the first Fsh cell can already be observed in the pituitary after $8 \mathrm{dpf}$. This is prior to the observation of the first pituitary Lh cells which arise at $14 \mathrm{dpf}$ (Hildahl et al. 2012). This is comparable to zebrafish, where Fsh arise before Lh cells ( 4 and 28 dpf for Fsh and Lh cells, respectively (Golan et al. 2014)). Contrary to what has been previously described for Lh cells (Hildahl et al. 2012), we did not observe any Fsh cell outside of the pituitary in medaka. We then observed that similar to in Lh cells (Fontaine et al. 2019), the number of Fsh cells as well as the percentage of cells they represent in the pituitary increase between juvenile and adult stages. In addition, we demonstrate that the cell volume is also increasing between juvenile and adult stages, which is in agreement with the previous observation where $\mathrm{Lh}$ cell size was also observed to increase. Therefore, both the proportion and the cell volume of gonadotropes

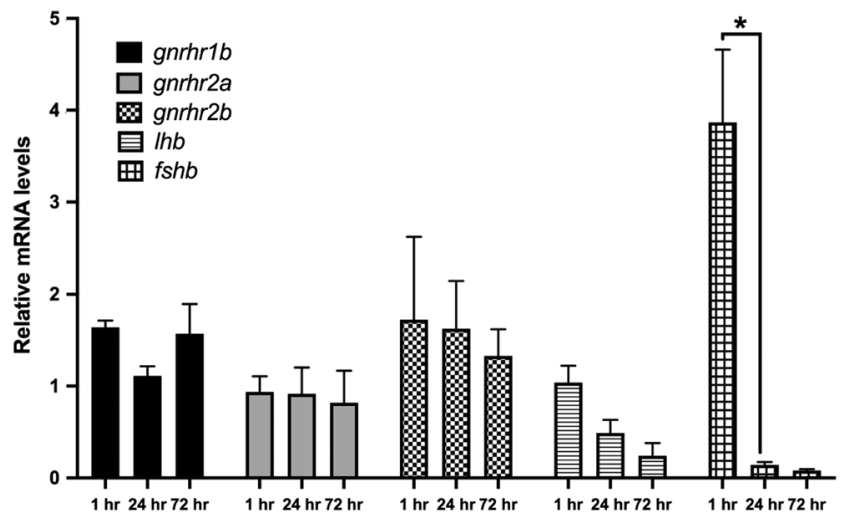

Figure 8

Temporal relative mRNA levels for Ihb, fshb, gnrhr1b, gnrhr2a and gnrhr2b in cell culture from $\operatorname{tg}(/ h b$-hrGfpll) adult female pituitaries. The mRNA levels of the genes of interest were reported to the level of a combination of reference genes including rp/7, gapdh and 18s RNA. Data were tested for normal distribution with the Shapiro-Wilk normality test, and two-way ANOVA with Tukey's multiple comparison test revealed significant differences ( ${ }^{*}$ when $P<0.05$ ).

(Lh and Fsh) are increasing in the medaka pituitary between juveniles and adults in both sex, certainly because reproduction plays a more important role in adults. These observations are similar to in mammals where an increasing number and size of gonadotropes has been observed during diestrus (Childs 1986, 1995). Interestingly, we noticed that the proportion of Lh cells is higher than for Fsh, in both juveniles (approximately 11 and 6\%, respectively) and adults (approximately 13 and $10 \%$, respectively).

Three hypotheses can explain the increasing number of gonadotropes in the pituitary. First, the division and differentiation of some progenitor cells. Second, the division of the gonadotrope themselves, and third, a phenotypic conversion of some of the differentiated pituitary cells. While the first hypothesis seems to have a primary role in mammalian pituitary plasticity (Florio 2011) and cannot be ruled out as some multipotent progenitor cells have been described previously in the dorsal part of the medaka pituitary (Fontaine et al. 2019), we focused our work on the two last hypotheses.

Proliferation has previously been described for Lh cells in the medaka pituitary, and here we demonstrate that this is also the case for Fsh cells. PCNA, an essential protein for DNA replication during the cell cycle, and BrdU which has been demonstrated to be a useful and reliable marker for labelling recently divided and currently dividing cells (Bauer \& Patterson 2005), were both observed in Fsh cells, confirming active cell division. Division of hormone producing cells is not restricted to fish as this has also been observed in the mammalian pituitary 
(Kominami et al. 2003) including gonadotropes themselves (Childs \& Unabia 2001).

Sex steroids play crucial roles in multiple systems related to reproduction, and $\mathrm{E} 2$ has been shown to play an essential role in medaka reproduction (Kayo et al. 2019). While the number of Fsh cells as well as Lh cells labelled by BrdU increased after $\mathrm{E} 2$ or testosterone treatment in males, this was not the case following treatment with 11-KT (a non-aromatizable androgen). These results therefore suggest that $\mathrm{E} 2$, and testosterone after aromatization into E2, are able to promote both Fsh and Lh cell proliferation in male medaka. In females however, only testosterone was able to increase the proliferation of Fsh cells. These results are in agreement with our previous study where we observed a stimulatory effect of E2 on Lh cell proliferation in males but not in females (Fontaine et al. 2019), perhaps due to higher endogenous levels of E2 in females (Bhatta et al. 2012, Kayo et al. 2020). Several studies have addressed the role of $\mathrm{E} 2$ and aromatizable androgens on the activity of Lh and Fsh cells in both mammals (Nett et al. 2002) and fish (Yaron et al. 2003, Zohar et al. 2010). In mammals, some studies have reported a negative effects of steroids on gonadotrope cell proliferation: Mitotic gonadotropes drastically increase after castration in male rats (Sakuma et al. 1984), and ovariectomy in female rats (Smith \& Keefer 1982). In fish, almost nothing is known about the role of steroids on gonadotrope cell proliferation. On gonadotrope cell activity, the effect of steroids has been shown to diverge depending on the species and the physiological state of the fish. Both positive and negative feedback have been observed. E2 and androgen treatments have been shown to inhibit gonadotrope activity in Indian catfish (Sundararaj \& Goswami 1968), goldfish (Billard \& Peter 1977), and rainbow trout (Billard \& Reinaud 1978) pituitary. But other studies have reported positive effects of E2 and aromatizable androgens on gonadotrope cells, such as in Atlantic salmon (Crim \& Peter 1978), European eel (Olivereau \& Olivereau 1979) and rainbow trout (Crim et al. 1981). Indeed, testosterone and $\mathrm{E} 2$ have previously been shown to enhance Gnrh-stimulated Lh release in Rainbow trout (Crim \& Evans 1983), goldfish (Trudeau et al. 1991), Atlantic croaker (Khan et al. 1999) and Black Porgy (Yen et al. 2002). Trudeau and colleagues hypothesized that the positive action of sex steroids on Gnrh responsiveness was due to an increase in pituitary Gnrh receptor number, although they could not demonstrate effect on pituitary Gnrh affinity or receptor number, in vitro (Trudeau et al. 1993). In medaka, we describe a positive effect of $\mathrm{E} 2$ and testosterone, on the proliferation of both gonadotrope cell types, therefore suggesting that testosterone and E2 may have an additional role on gonadotrope cells by controlling their proliferation. Whether testosterone and E2 enhance Gnrh-stimulated Lh release in medaka and if this effect involves the proliferation of gonadotrope cells remain to be investigated.

In this study, we used relatively high doses of steroids $(100 \mu \mathrm{g} / \mathrm{L})$. These doses have previously been used in medaka (El-Alfy \& Schlenk 2002, Fontaine et al. 2019) and shown to be the lowest dose that significantly increase E2 plasma levels after 7 days of treatment (Thompson 2000). Interestingly, a recent study tested different techniques for steroid administration and showed that lower concentrations of E2 can be used to increase E2 plasma level in medaka and that medaka seems to bioconcentrate E2 in the blood (Kayo et al. 2020). However, the authors investigated the plasma level of E2 for only $24 \mathrm{~h}$ after E2 treatment, thus further experiments need to be done, with different exposure times and concentrations, to clearly identify the role of steroids on the different components of the BPG axis including gonadotrope cell proliferation. Also, while the vehicle (ethanol) used in this study was highly diluted $\left(1: 10^{5}\right)$ as compared to previous studies (1:102-1:104) discussed in von Krogh et al. (2019), whether the vehicle can have an effect on pituitary cell proliferation remains to be investigated. Finally, we confirm the results observed in Fontaine et al. (2019) and show that some Lh cells express aromatase. In addition, we found that some Fsh cells also express aromatase suggesting that they may participate in the control of their own proliferation.

To test the third hypothesis about phenotypic plasticity we used the double transgenic line. We observed some gonadotropes labelled by both hrGfpII and DsRed2 in adult and juvenile stages suggesting that some cells could express both gonadotropic hormones in the medaka pituitary. We then confirmed that some cells were expressing both $l h b$ and $f s h b$ mRNA using two colour FISH technique. Dual phenotype has been reported in other teleost fish, including the Mediterranean yellowtail (Hernandez et al. 2002), European hake (Candelma et al. 2017), zebrafish and tilapia (Golan et al. 2014). It is presently unknown whether these cells are progenitor cells in a transient phenotype of differentiation towards one hormone phenotype, or fully differentiated gonadotropes in a transient form during the phenotypic conversion from one hormone phenotype to another or simply with permanent bi-hormonal phenotype. Lh and Fsh cells have been shown to share the same developmental path (Weltzien et al. 2014), and the presence of Fsh cells 
has been revealed in the ventral surface of the pituitary in larval and juvenile stages, in close proximity to the Lh cells. However, we never observed dual labelling in pituitary cells of $14 \mathrm{dpf}$ old larvae, the time when the first Lh cells arise. Instead, we could observe some weakly labelled hrGfpII or DsRed2 cells, suggesting that new gonadotropes arise as monohormonal cells. Therefore, the dual phenotype gonadotropes is probably not expressed in differentiating progenitor cells, but more likely in cells that change phenotype at a later stage.

We found that Lh and Fsh cells are similar in morphology. They have similar volume in juveniles and in adults and show, both in vivo and in vitro, extensions allowing networking as previously shown for Lh (Grønlien et al. 2019). Here, we show that Lh and Fsh cells show similar behaviour as they connect and cluster in cell culture using these extensions. While these similarities suggest a similar genetic background, which has already been shown (Weltzien et al. 2014), they would also make it easy for a phenotypic conversion between the two phenotypes. We previously reported that some cells from unknown identity where able to start to produce Lh with time in cell culture (Fontaine et al. 2019). Here, we demonstrated that in cell culture, some Fsh cells can change phenotype and start to produce $l h b$, and that Gnrh stimulates this phenotypic conversion. Interestingly, we did not observe any obvious decrease of DsRed2 fluorescence in the Fsh cells suggesting that the Fsh cells may become bi-hormonal, but fluorescent reporter proteins have usually relatively long half-life (about 24-30 h in mammalian cells) (Corish \& TylerSmith 1999). In addition, we observed that levels of $f s h b$ mRNA were drastically reduced after $24 \mathrm{~h}$ in cell culture, but we cannot identify which cells are responsible for this decrease. It is therefore impossible to determine if the cells that start to produce $l \mathrm{hb}$ become Lh-monohormonal or bi-hormonal cells. As the $\operatorname{tg}(\mathrm{lhb}$ :hrGfp) line is BAC-based it should widely include all possible enhancer regions of the $l h b$ gene suggesting that the control observed on hrGfpII expression indeed occurs for $l h b$ expression. This was further supported by our observation of some hrGfpII/ DsRed2 cells found to contain $\operatorname{Lh} \beta$. Indeed, we observed that while none of the Fsh cells were producing $\operatorname{Lh} \beta$ after dissociation, several Fsh cells were found labelled for $\operatorname{Lh} \beta$ after 3 days in cell culture with Gnrh1. In addition, these DsRed2/Lh $\beta$ cells were shown to be also hrGfpII-positive using the double transgenic line. It should be noted that we never observed Lh cells becoming Fsh positive. These results are similar to the one observed in vitro in rats
(Childs 1985) where mono-hormonal Fsh cells have been found to become bi-hormonal when stimulated with Gnrh. This phenotypic conversion of Fsh cells has also been described in vivo in the Rhesus Monkey during sexual maturation (Meeran et al. 2003). In addition, it has already been described in rats (Denef et al. 1978) and sheep (Taragnat et al. 1998), that Gnrh was responsible for a change in the pituitary gonadotrope population by regulating the existence of LH-monohormonal, FSHmonohormonal and bi-hormonal gonadotrope subtypes. Whether this phenomenon is reversible and if other compounds could have similar or opposite effects, remains to be tested. These experiments also need to be performed ex vivo to confirm that in medaka, phenotypic plasticity is not just due to cell culture conditions.

It is also interesting to notice that while Gnrh promotes phenotypic conversion and thus increases the number of double labelled cells in vitro, a lower number of double labelled cells were observed in vivo (where gonadotropes could receive Gnrh input) than in vitro. These observations suggest that something prevents the phenotypic conversion of Fsh cells by Gnrh in vivo. It has recently been shown that in adult female medaka, in vivo Fsh cells do not possess any gnrhr, and do not respond (electrically nor by changes in cytosolic $\mathrm{Ca}^{2+}$ levels) to Gnrh stimuli after dissociation and maintained for a short period in culture (less than $48 \mathrm{~h}$ (Hodne et al. 2019)). Here, we show that after 3 days in cell culture, a subset of Fsh cells (about $50 \%)$ start responding to Gnrh stimuli by increasing the intracellular calcium concentration. This suggests that Fsh cells are changing phenotypic characteristics after being cultivated for an extended time without close contact with other cells and without brain and feedback inputs, may start to produce gnrhr. However, we did not observe any increase of gnrhr expression in medaka pituitary cell culture. This may be due to the relatively low number of Fsh cells in our cultures or/and the relatively high expression of gnrhr in the other pituitary cell types, thus hiding small increases of expression by Fsh cells. Indeed, a study in cod primary pituitary cell culture has reported an increase of the gene expression levels between day 2 and day 7 of one Gnrh-receptor (Gnrhr2a) found to be expressed in gonadotropes in this species (Hodne et al. 2012). Together, these observations suggest that Fsh cells need an unknown input to maintain their Fsh-only phenotype by preventing Gnrh-receptor expression in Fsh cells in vivo, such as described in Fig. 9. Further studies are needed to identify the factors playing a role in the maintenance of Fsh status and its origin (brain, gonads https://joe.bioscientifica.com https://doi.org/10.1530/JOE-19-0405 (c) 2020 The authors Published by Bioscientifica Ltd. Printed in Great Britain

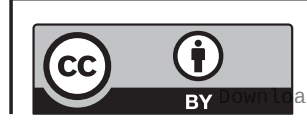

This work is licensed under a Creative Commons Attribution 4.0 International License. ed from Bioscientifica.com at 04/26/2023 07:47:57AM 


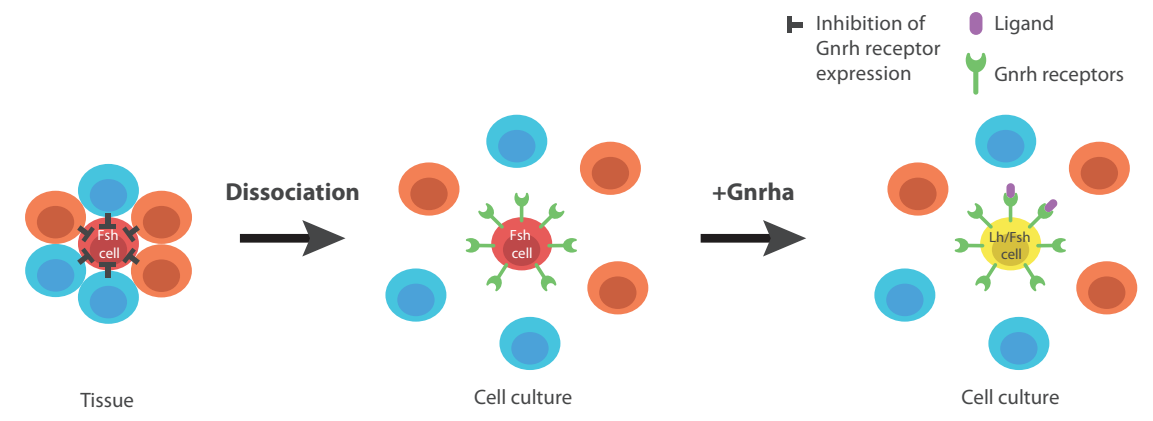

\section{Figure 9}

Schematic drawing of the working hypothesis. After dissociation, Fsh cells seem to start to express Gnrh receptors while they do not in vivo according to Hodne et al. (2019). Therefore, an unknown factor is preventing the expression of Gnrh receptors by Fsh cells in vivo. After dissociation, this factor is removed and some Fsh cells become able to respond to Gnrh stimuli. Application of Gnrh is then able to promote the expression of Ihb in the Fsh cells that express Gnrh receptors and have become Gnrh sensitive. or pituitary itself), but the recent study from Hodne et al. 2019 showing that gonadotropes form heteroand homotypic networks makes the hypothesis of an important paracrine factor loss by the dissociation process highly relevant. These observations further support that precautions should be taken about the conclusions when investigating dissociated primary pituitary cell cultures over time.

Many groups have reported a direct stimulation of Fsh cells by Gnrh in cell culture. While we observed that some Fsh cells start to produce $\operatorname{lhb}$ after only 15 hours in medaka cell culture, most in vitro studies use the cells several days after they were dissociated and plated: more than 3 days for coho salmon (Dickey \& Swanson 2000), 5 days for rainbow trout (Vacher et al. 2000), 2 days for masu salmon (Ando et al. 2004), and more than 2 days for Atlantic cod (Hodne et al. 2013). In addition, other studies have shown an effect of Gnrh on Fsh cells in more complete systems (pituitary slices or whole pituitary), where cells are kept in a more intact environment and connections with neighbouring cells are preserved (tilapia (Aizen et al. 2007) and medaka (Karigo et al. 2014)), but a recent study showed that Fsh cells can be activated indirectly through heterotypic pituitary cell networks in medaka (Hodne et al. 2019). Therefore, whether Gnrh directly affects Fsh cells in fish should be reinvestigated taking these new findings into account.

To conclude, this study demonstrates that gonadotropes, Lh and Fsh cells, show high plasticity by exhibiting hypertrophy and hyperplasia between juvenile and adult stages. They both proliferate in the medaka pituitary upon estradiol and aromatizable androgen stimulation, and may participate in the control of their own proliferation as they both express aromatase. Fsh cells have the capacity to change their phenotype by starting to produce Lh, and this phenomenon is promoted by Gnrh, and seemingly prevented by an unknown factor in vivo. This may explain the low number of gonadotropes observed as bi-hormonal in different fish species. Combined, these two phenomena may participate in adapting hormone production to hormone demand, which differs across the life span of an animal. It also reveals that fish gonadotropes are more similar to the mammalian gonadotropes than we have anticipated.

\section{Supplementary materials}

This is linked to the online version of the paper at https://doi.org/10.1530/ JOE-19-0405.

\section{Declaration of interest}

The authors declare that there is no conflict of interest that could be perceived as prejudicing the impartiality of the research reported.

\section{Funding}

This work was funded by the Norwegian University of Life Sciences and by the Research Council of Norway, grant numbers 244461 and 243811 (Aquaculture program) and 248828 (Digital Life Norway program).

\section{Ethics approval}

Animal experiments were performed according to the recommendations of the care and welfare of research animals at the Norwegian University of Life Sciences, with specific approval from the Norwegian Food Safety Authority (FOTS ID 8596).

\section{Author contribution statement}

R F, E A W, K H made the experiments. R F, E A W, K H and F A W conceived the research and analyzed the data. $R F$ wrote the manuscript, with input from the other authors.

\section{Acknowledgements}

The authors are grateful to Dr Nourizadeh-Lillabadi Rasoul for qPCR analyses, Dr Susann Burow for taking part in generating the fsh transgenic line as well as Dr John Hildahl for larval sampling during early development, and Lourdes Carreon G Tan for fish facility maintenance.
(C) 2020 The authors Published by Bioscientifica Ltd. Printed in Great Britain
This work is licensed under a Creative Commons Attribution 4.0 International License.

ded from Bioscientifica.com at 04/26/2023 07:47:57AM 


\section{References}

Ager-Wick E, Hodne K, Fontaine R, Von Krogh K, Haug TM \& Weltzien FA 2018 Preparation of a high-quality primary cell culture from fish pituitaries. Journal of Visualized Experiments 138 e58159. (https://doi. org $/ 10.3791 / 58159)$

Aizen J, Kasuto H, Golan M, Zakay H \& Levavi-Sivan B 2007 Tilapia follicle-stimulating hormone (FSH): immunochemistry, stimulation by gonadotropin-releasing hormone, and effect of biologically active recombinant FSH on steroid secretion. Biology of Reproduction $\mathbf{7 6}$ 692-700. (https://doi.org/10.1095/biolreprod.106.055822)

Ando H, Swanson P, Kitani T, Koide N, Okada H, Ueda H \& Urano A 2004 Synergistic effects of salmon gonadotropin-releasing hormone and estradiol-17beta on gonadotropin subunit gene expression and release in masu salmon pituitary cells in vitro. General and Comparative Endocrinology 137 109-121. (https://doi.org/10.1016/j. ygcen.2004.02.012)

Bauer S \& Patterson PH 2005 The cell cycle-apoptosis connection revisited in the adult brain. Journal of Cell Biology 171 641-650. (https://doi.org/10.1083/jcb.200505072)

Bhatta S, Iwai T, Miura C, Higuchi M, Shimizu-Yamaguchi S, Fukada H \& Miura T 2012 Gonads directly regulate growth in teleosts. PNAS 109 11408-11412. (https://doi.org/10.1073/pnas.1118704109)

Billard R \& Peter RE 1977 Gonadotropin release after implantation of anti-estrogens in the pituitary and hypothalamus of goldfish Carassius auratus. General and Comparative Endocrinology 32 213-220. (https://doi.org/10.1016/0016-6480(77)90154-x)

Billard R \& Reinaud P 1978 Testicular feed back on the hypothalamopituitary axis in rainbow trout (Salmo gairdneri R.). Annales de Biologie Animale, Biochimie, Biophysique 18 813-818. (https://doi.org/10.1051/ rnd:19780509)

Burow S, Fontaine R, von Krogh K, Mayer I, Nourizadeh-Lillabadi R, Hollander-Cohen L, Cohen Y, Shpilman M, Levavi-Sivan B \& Weltzien FA 2019 Medaka follicle-stimulating hormone (Fsh) and luteinizing hormone (Lh): developmental profiles of pituitary protein and gene expression levels. General and Comparative Endocrinology 272 93-108. (https://doi.org/10.1016/j.ygcen.2018.12.006)

Candelma M, Fontaine R, Colella S, Santojanni A, Weltzien FA \& Carnevali O 2017 Gonadotropin characterization, localization and expression in the European hake (Merluccius merluccius). Reproduction 153 123-132. (https://doi.org/10.1530/REP-16-0377)

Carpenter AE, Jones TR, Lamprecht MR, Clarke C, Kang IH, Friman O, Guertin DA, Chang JH, Lindquist RA, Moffat J, et al. 2006 CellProfiler: image analysis software for identifying and quantifying cell phenotypes. Genome Biology 7 R100. (https://doi.org/10.1186/ gb-2006-7-10-r100)

Childs GV 1983 Application of dual pre-embedding stains for gonadotropins to pituitary cell monolayers with avidin-biotin (abc) and peroxidase-antiperoxidase (pap) complexes - light microscopic studies. Stain Technology $\mathbf{5 8}$ 281-289. (https://doi. org/10.3109/10520298309066800)

Childs GV 1985 Shifts in gonadotropin storage in cultured gonadotropes following GnRH stimulation, in vitro. Peptides 6 103-107. (https:// doi.org/10.1016/0196-9781(85)90084-1)

Childs GV 1986 Functional ultrastructure of gonadotropes: a review. In Morphology of Hypothalamus and Its Connections, pp 49-97. Eds D Ganten \& D Pfaff. Berlin, Heidelberg, Germany: Springer. (https://doi. org/10.1007/978-3-642-71461-0_2)

Childs GV 1995 Division of labor among gonadotropes. In Vitamins and Hormones, pp 215-286. Ed G Litwack. Cambridge, MA, USA: Academic Press. (https://doi.org/10.1016/S0083-6729(08)60657-3)

Childs GV \& Unabia G 2001 Epidermal growth factor and gonadotropinreleasing hormone stimulate proliferation of enriched population of gonadotropes. Endocrinology 142 847-853. (https://doi.org/10.1210/ endo.142.2.7953)
Childs GV, Ellison DG, Lorenzen JR, Collins TJ \& Schwartz NB 1982 Immunocytochemical studies of gonadotropin storage in developing castration cells. Endocrinology 111 1318-1328. (https://doi. org/10.1210/endo-111-4-1318)

Corish P \& Tyler-Smith C 1999 Attenuation of green fluorescent protein half-life in mammalian cells. Protein Engineering 12 1035-1040. (https://doi.org/10.1093/protein/12.12.1035)

Crim LW \& Evans DM 1983 Influence of testosterone and/or luteinizing hormone releasing hormone analogue on precocious sexual development in the juvenile rainbow trout. Biology of Reproduction 29 137-142. (https://doi.org/10.1095/biolreprod29.1.137)

Crim LW \& Peter RE 1978 The influence of testosterone implantation in the brain and pituitary on pituitary gonadotropin levels in Atlantic salmon parr. Annales de Biologie Animale, Biochimie, Biophysique 18 689-694. (https://doi.org/10.1051/rnd:19780405)

Crim LW, Peter RE \& Billard R 1981 Onset of gonadotropic hormone accumulation in the immature trout pituitary gland in response to estrogen or aromatizable androgen steroid hormones. General and Comparative Endocrinology 44 374-381. (https://doi.org/10.1016/00166480(81)90015-0)

Denef C, Hautekeete E \& Dewals R 1978 Monolayer cultures of gonadotrophs separated by velocity sedimentation: heterogeneity in response to luteinizing hormone-releasing hormone. Endocrinology 103 736-747. (https://doi.org/10.1210/endo-103-3-736)

Dickey JT \& Swanson P 2000 Effects of salmon gonadotropin-releasing hormone on follicle stimulating hormone secretion and subunit gene expression in coho salmon (Oncorhynchus kisutch). General and Comparative Endocrinology 118 436-449. (https://doi.org/10.1006/ gcen.2000.7482)

Edelstein AD, Tsuchida MA, Amodaj N, Pinkard H, Vale RD \& Stuurman N 2014 Advanced methods of microscope control using $\mu$ Manager software. Journal of Biological Methods $\mathbf{1}$ e10. (https://doi. org $/ 10.14440 / \mathrm{jbm} .2014 .36$ )

El-Alfy AT \& Schlenk D 2002 Effect of 17beta-estradiol and testosterone on the expression of flavin-containing monooxygenase and the toxicity of aldicarb to Japanese medaka, Oryzias latipes. Toxicological Sciences 68 381-388. (https://doi.org/10.1093/toxsci/68.2.381)

Florio T 2011 Adult pituitary stem cells: from pituitary plasticity to adenoma development. Neuroendocrinology 94 265-277. (https://doi. org/10.1159/000330857)

Fontaine R, Affaticati P, Yamamoto K, Jolly C, Bureau C, Baloche S, Gonnet F, Vernier P, Dufour S \& Pasqualini C 2013 Dopamine inhibits reproduction in female zebrafish (Danio rerio) via three pituitary D2 receptor subtypes. Endocrinology 154 807-818. (https://doi. org/10.1210/en.2012-1759)

Fontaine R, Hodne K \& Weltzien FA 2018 Healthy brain-pituitary slices for electrophysiological investigations of pituitary cells in teleost fish. Journal of Visualized Experiments 138 e57790. (https://doi. org/10.3791/57790)

Fontaine R, Ager-Wick E, Hodne K \& Weltzien FA 2019 Plasticity of Lh cells caused by cell proliferation and recruitment of existing cells. Journal of Endocrinology 240 361-377. (https://doi.org/10.1530/JOE18-0412)

Golan M, Biran J \& Levavi-Sivan B 2014 A novel model for development, organization, and function of gonadotropes in fish pituitary. Frontiers in Endocrinology 5 182. (https://doi.org/10.3389/fendo.2014.00182)

Grønlien HK, Fontaine R, Hodne K, Tysseng I, Ager-Wick E, Weltzien FA \& Haug TM 2019 Gonadotropes in medaka grow long extensions with varicosity-like swellings, projecting towards each other and blood vessels. bioRxiv 777151. (https://doi.org/10.1101/777151)

Harris GW 1951 Neural control of the pituitary gland. I. The neurohypophysis. BMJ 2 559-564. (https://doi.org/10.1136/ bmj.2.4731.559)

Hildahl J, Sandvik GK, Lifjeld R, Hodne K, Nagahama Y, Haug TM, Okubo K \& Weltzien FA 2012 Developmental tracing of luteinizing hormone beta-subunit gene expression using green fluorescent

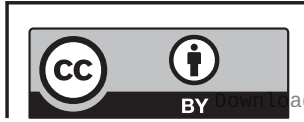

This work is licensed under a Creative Commons Attribution 4.0 International License. 
protein transgenic medaka (Oryzias latipes) reveals a putative novel developmental function. Developmental Dynamics 241 1665-1677. (https://doi.org/10.1002/dvdy.23860)

Hodne K, von Krogh K, Weltzien FA, Sand O \& Haug TM 2012. The importance of osmolality, $\mathrm{pCO}(2)$. General and Comparative Endocrinology 178 206-215. (https://doi.org/10.1016/j. ygcen.2012.06.005)

Hodne K, Strandabo RA, von Krogh K, Nourizadeh-Lillabadi R, Sand O, Weltzien FA \& Haug TM 2013 Electrophysiological differences between fshb- and lhb-expressing gonadotropes in primary culture. Endocrinology 154 3319-3330. (https://doi.org/10.1210/en.2013-1164)

Hodne K, Fontaine R, Ager-Wick E \& Weltzien FA 2019 Gnrh1-induced responses are indirect in female medaka Fsh cells, generated through cellular networks. Endocrinology 160 3018-3032. (https://doi. org/10.1210/en.2019-00595)

Kanda S, Okubo K \& Oka Y 2011 Differential regulation of the luteinizing hormone genes in teleosts and tetrapods due to their distinct genomic environments - insights into gonadotropin beta subunit evolution. General and Comparative Endocrinology 173 253-258. (https://doi. org/10.1016/j.ygcen.2011.05.015)

Karigo T, Aikawa M, Kondo C, Abe H, Kanda S \& Oka Y 2014 Whole brain-pituitary in vitro preparation of the transgenic medaka (Oryzias latipes) as a tool for analyzing the differential regulatory mechanisms of LH and FSH release. Endocrinology 155 536-547. (https://doi. org/10.1210/en.2013-1642)

Kayo D, Oka Y \& Kanda S 2020 Examination of methods for manipulating serum $17 \beta$-estradiol (E2) levels by analysis of blood E2 concentration in medaka (Oryzias latipes). General and Comparative Endocrinology 285 113272. (https://doi.org/10.1016/j. ygcen.2019.113272)

Kayo D, Zempo B, Tomihara S, Oka Y \& Kanda S 2019 Gene knockout analysis reveals essentiality of estrogen receptor $\beta 1$ (Esr2a) for female reproduction in medaka. Scientific Reports 9 8868. (https://doi. org/10.1038/s41598-019-45373-y)

Khan IA, Hawkins MB \& Thomas P 1999 Gonadal stage-dependent effects of gonadal steroids on gonadotropin II secretion in the Atlantic croaker (Micropogonias undulatus). Biology of Reproduction 61 834-841. (https://doi.org/10.1095/biolreprod61.3.834)

Kominami R, Yasutaka S, Taniguchi Y \& Shinohara H 2003 Proliferating cells in the rat anterior pituitary during the postnatal period: immunoelectron microscopic observations using monoclonal antibromodeoxyuridine antibody. Histochemistry and Cell Biology 120 223-233. (https://doi.org/10.1007/s00418-003-0565-9)

Meeran D, Urbanski HF, Gregory SJ, Townsend J \& Tortonese DJ 2003 Developmental changes in the hormonal identity of gonadotroph cells in the rhesus monkey pituitary gland. Journal of Clinical Endocrinology and Metabolism 88 2934-2942. (https://doi.org/10.1210/ jc.2002-021001)

Nakane PK 1970 Classifications of anterior pituitary cell types with immunoenzyme histochemistry. Journal of Histochemistry and Cytochemistry 18 9-20. (https://doi.org/10.1177/18.1.9)

Nett TM, Turzillo AM, Baratta M \& Rispoli LA 2002 Pituitary effects of steroid hormones on secretion of follicle-stimulating hormone and luteinizing hormone. Domestic Animal Endocrinology 23 33-42. (https://doi.org/10.1016/s0739-7240(02)00143-1)

Nozaki M, Naito N, Swanson P, Miyata K, Nakai Y, Oota Y, Suzuki K \& Kawauchi H 1990 Salmonid pituitary gonadotrophs. I. Distinct cellular distributions of two gonadotropins, GTH I and GTH II. General and Comparative Endocrinology 77 348-357. (https://doi. org/10.1016/0016-6480(90)90224-a)

Okubo K, Takeuchi A, Chaube R, Paul-Prasanth B, Kanda S, Oka Y \& Nagahama Y 2011 Sex differences in aromatase gene expression in the medaka brain. Journal of Neuroendocrinology 23 412-423. (https://doi. $\operatorname{org} / 10.1111 / \mathrm{j} .1365-2826.2011 .02120 . x)$

Olivereau M \& Olivereau J 1979 Estradiol-positive feedback on gonadotropic (GTH) cells in freshwater male silver eels. General and
Comparative Endocrinology 39 247-261. (https://doi.org/10.1016/00166480(79)90119-9)

Pfaffl MW, Tichopad A, Prgomet C \& Neuvians TP 2004 Determination of stable housekeeping genes, differentially regulated target genes and sample integrity: BestKeeper-Excel-based tool using pairwise correlations. Biotechnology Letters 26 509-515. (https://doi. org/10.1023/b:bile.0000019559.84305.47)

Pilar García Hernández M, García Ayala A, Zandbergen MA \& Agulleiro B 2002 Investigation into the duality of gonadotropic cells of Mediterranean yellowtail (Seriola dumerilii, Risso 1810): immunocytochemical and ultrastructural studies. General and Comparative Endocrinology 128 25-35. (https://doi.org/10.1016/s00166480(02)00052-7)

Pogoda HM \& Hammerschmidt M 2007 Molecular genetics of pituitary development in zebrafish. Seminars in Cell and Developmental Biology 18 543-558. (https://doi.org/10.1016/j.semcdb.2007.04.004)

Sakuma S, Shirasawa N \& Yoshimura F 1984 A histometrical study of immunohistochemically identified mitotic adenohypophysial cells in immature and mature castrated rats. Journal of Endocrinology $\mathbf{1 0 0}$ 323-328. (https://doi.org/10.1677/joe.0.1000323)

Schindelin J, Arganda-Carreras I, Frise E, Kaynig V, Longair M, Pietzsch T, Preibisch S, Rueden C, Saalfeld S, Schmid B, et al. 2012 Fiji: an open-source platform for biological-image analysis. Nature Methods 9 676-682. (https://doi.org/10.1038/nmeth.2019)

Schmid B, Schindelin J, Cardona A, Longair M \& Heisenberg M 2010 A high-level 3D visualization API for Java and ImageJ. BMC Bioinformatics 11 274. (https://doi.org/10.1186/1471-2105-11-274)

Schmitz M, Aroua S, Vidal B, Le Belle N, Elie P \& Dufour S 2005 Differential regulation of luteinizing hormone and follicle-stimulating hormone expression during ovarian development and under sexual steroid feedback in the European eel. Neuroendocrinology 81 107-119. (https://doi.org/10.1159/000086404)

Shima A \& Mitani H 2004 Medaka as a research organism: past, present and future. Mechanisms of Development 121 599-604. (https://doi. org/10.1016/j.mod.2004.03.011)

Smith PF \& Keefer DA 1982 Immunocytochemical and ultrastructural identification of mitotic cells in the pituitary gland of ovariectomized rats. Journal of Reproduction and Fertility 66 383-388. (https://doi. org/10.1530/jrf.0.0660383)

Strandabo RA, Hodne K, Ager-Wick E, Sand O, Weltzien FA \& Haug TM 2013 Signal transduction involved in GnRH2-stimulation of identified LH-producing gonadotropes from lhb-GFP transgenic medaka (Oryzias latipes). Molecular and Cellular Endocrinology 372 128-139. (https://doi.org/10.1016/j.mce.2013.03.022)

Sundararaj BI \& Goswami SV 1968 Effects of estrogen, progesterone, and testosterone on the pituitary and ovary of catfish, Heteropneustes fossilis (Bloch). Journal of Experimental Zoology 169 211-219. (https:// doi.org/10.1002/jez.1401690208)

Taragnat C, Bernier A \& Fontaine J 1998 Gonadotrophin storage patterns in the ewe during the oestrous cycle or after long-term treatment with a GnRH agonist. Journal of Endocrinology 156 149-157. (https://doi. org/10.1677/joe.0.1560149)

Thompson SC 2000 Physiological indicators of endocrine disruptor exposure in Japanese Medaka (Oryzias latipes): relationship to reproduction and development. MS thesis. Oxford, MI, USA: University of Mississippi.

Trudeau VL, Peter RE \& Sloley BD 1991 Testosterone and estradiol potentiate the serum gonadotropin response to gonadotropinreleasing hormone in goldfish. Biology of Reproduction 44 951-960. (https://doi.org/10.1095/biolreprod44.6.951)

Trudeau VL, Murthy CK, Habibi HR, Sloley BD \& Peter RE 1993 Effects of sex steroid treatments on gonadotropin-releasing hormonestimulated gonadotropin secretion from the goldfish pituitary. Biology of Reproduction 48 300-307. (https://doi.org/10.1095/ biolreprod48.2.300)

Vacher C, Mananos EL, Breton B, Marmignon MH \& Saligaut C 2000 Modulation of pituitary dopamine D1 or D2 receptors and secretion

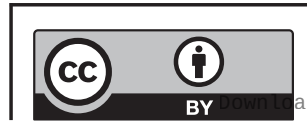

This work is licensed under a Creative Commons Attribution 4.0 International License. 
of follicle stimulating hormone and luteinizing hormone during the annual reproductive cycle of female rainbow trout. Journal of Neuroendocrinology 12 1219-1226. (https://doi.org/10.1046/j.13652826.2000.00585.x)

von Krogh K, Bjorndal GT, Nourizadeh-Lillabadi R, Ropstad E, Haug TM \& Weltzien FA 2019 Cortisol differentially affects cell viability and reproduction-related gene expression in Atlantic cod pituitary cultures dependent on stage of sexual maturation. Comparative Biochemistry and Physiology: Part A, Molecular and Integrative Physiology 236 110517. (https://doi.org/10.1016/j.cbpa.2019.06.017)

Weltzien FA, Andersson E, Andersen $\varnothing$, Shalchian-Tabrizi K \& Norberg B 2004 The brain-pituitary-gonad axis in male teleosts, with special emphasis on flatfish (Pleuronectiformes). Comparative Biochemistry and Physiology: Part A, Molecular and Integrative Physiology 137 447-477. (https://doi.org/10.1016/j.cbpb.2003.11.007)

Weltzien FA, Pasqualini C, Vernier P \& Dufour S 2005 A quantitative realtime RT-PCR assay for European eel tyrosine hydroxylase. General and Comparative Endocrinology 142 134-142. (https://doi.org/10.1016/j. ygcen.2004.12.019)
Weltzien FA, Hildahl J, Hodne K, Okubo K \& Haug TM 2014 Embryonic development of gonadotrope cells and gonadotropic hormoneslessons from model fish. Molecular and Cellular Endocrinology 385 18-27. (https://doi.org/10.1016/j.mce.2013.10.016)

Wittbrodt J, Shima A \& Schartl M 2002 Medaka - a model organism from the far East. Nature Reviews: Genetics 3 53-64. (https://doi. org/10.1038/nrg704)

Yaron Z, Gur G, Melamed P, Rosenfeld H, Elizur A \& Levavi-Sivan B 2003 Regulation of fish gonadotropins. International Review of Cytology $\mathbf{2 2 5}$ 131-185. (https://doi.org/10.1016/s0074-7696(05)25004-0)

Yen FP, Lee YH, He CL, Huang JD, Sun LT, Dufour S \& Chang CF 2002 Estradiol-17 $\beta$ triggers luteinizing hormone release in the protandrous Black porgy (Acanthopagrus schlegeli Bleeker) through multiple interactions with gonadotropin-releasing hormone control. Biology of Reproduction 66 251-257. (https://doi.org/10.1095/ biolreprod66.1.251)

Zohar Y, Munoz-Cueto JA, Elizur A \& Kah O 2010 Neuroendocrinology of reproduction in teleost fish. General and Comparative Endocrinology 165 438-455. (https://doi.org/10.1016/j.ygcen.2009.04.017)

Received in final form 7 January 2020

Accepted 23 January 2020

Accepted Manuscript published online 24 January 2020
This work is licensed under a Creative Commons Attribution 4.0 International License. 